\title{
Earnings Management in Firms Seeking to Be Acquired
}

\author{
Seraina C. Anagnostopoulou ${ }^{1}$
}

Andrianos E. Tsekrekos

\author{
Department of Accounting \& Finance, \\ Athens University of Economics \& Business (AUEB), \\ 76 Patision Str., GR10434, Athens, Greece.
}

This version: July 2012

\begin{abstract}
$\underline{\text { Abstract }}$
Empirical evidence regarding accrual-based earnings management around mergers and acquisitions has been setting-specific as far as target firms are concerned. This might be due to the fact that target firms cannot anticipate an acquisition proposal, and thus lack the motive and the time necessary to manage their earnings in order to facilitate or impede the deal. In this paper, we provide clear evidence of downwards earnings management by a sample of target firms that have both time and motive to engage in such actions. These are firms that publicly announce their intention to be acquired. Publicly 'seeking a buyer' represents a rather unusual corporate event, and we find that these firms engage in downwards earnings management in the years surrounding the 'announcement year'. To some extent, this result is explained by overrepresentation of low growth and distress among these firms, but is still consistent with engaging in 'big bath' accounting in the year of the event. Furthermore, we show that such downwards earnings management negatively affects market performance around the announcement, and also the probability for a firm to secure an acquisition within a reasonable amount of time, indicative of prospective buyers having a preference for firms not "seeking buyer" under performance-related pressures.

JEL classification: M41, G34
\end{abstract}

Keywords: acquisition targets, takeovers, earnings management, income manipulation

\footnotetext{
${ }^{1}$ Corresponding author; Email: sanagnosto@aueb.gr, Tel: +30 2108203442.
} 


\section{Earnings Management in Firms Seeking to Be Acquired}

\section{Introduction}

Existing research has first identified accrual-based earnings management around (stock swap) mergers and acquisitions from the side of the acquirer, in an effort to inflate earnings, increase the stock price and improve the exchange ratio, which is inversely related to the stock price (Erikson and Wang, 1999; Louis, 2004).

In the case of accrual-based earnings management by target firms, empirical evidence is more limited as the possible motivation for earnings management prior to a takeover, as well as the relevant opportunity, are more challenging to tackle, compared to the motives of acquirers. Target firms are in many cases not the deal initiators, and thus lack the time to adjust their financial statements to affect the bid price. Empirical evidence on acquisition targets and accrual-based earnings management (hereafter EM) has been rather setting-specific, depending, for example, on whether the acquisition is friendly or not, or takes place via an auction as opposed to negotiation: previous studies find positive, not always significant EM for targets (Erikson and Wang, 1999), positive evidence for EM in the case of hostile, as opposed to friendly takeovers (Easterwood,1998), downwards EM for targets of friendly acquisitions (Eddey and Taylor, 1998; Ben-Amar and Misisoner-Piera, 2008), and, more recently, positive EM in target firms acquired via auction vs. negotiation (Anilowski et al., 2009).

This study receives motivation from previous research that tests for EM in target firms after an acquisition has taken place or been announced, and investigates the existence of earnings management by firms which engage in a rather unusual corporate event: openly and publicly seeking a buyer. These are firms that at some point of their corporate history have announced that they are in the process of reviewing strategic alternatives for the firm's assets, including the possible sale or merger of the company. Such firms would typically attain the services of 
an investment bank or a financial institution to provide financial advice and facilitate the review of alternative actions. This study is centered on the hypothesis that earnings management may be a means employed by such firms to facilitate the sale of their assets.

The strategy to publicly seek a buyer is indeed quite unusual and has been rather neglected by previous research. To the best of our knowledge, there exists one recent study by Murdock and Madura (2011) which investigates the characteristics of U.S. firms publicly seeking a buyer, and the outcome of this announcement in terms of finding a buyer. As they argue, the decision to publicly seek a buyer may have advantages and disadvantages. On one hand, there is no need to rely on intermediaries to contact possible bidders, and the bidder may face less resistance from the side of the target, making the deal more attractive for potential acquirers. On the other hand, the target might sound 'desperate' or have previously failed to find a buyer through private negotiations, or potential bidders might be deterred by the fact that the bidding process may end up being too competitive (Murdock and Madura, 2011).

We examine EM in relation to this corporate event because as Lo (2008) points out, the practice of EM, as is the case with a crime, requires the existence of both motive and opportunity. It is thus questionable whether all target firms, as non-initiators of M\&A transactions, have these two attributes. However, in this study we focus on a subgroup of possible targets which by no means act as passive parties in a possible transaction: firms publicly seeking a buyer have both the time, motivation and opportunity to influence their reported numbers in a way that can affect the contractual outcome of their scope (find a buyer), following the definition of EM by Healy and Wahlen (1999).

We first argue that firms seeking to be acquired constitute a setting with motivation for EM to achieve corporate goals. We identify two possible motivations for EM in firms seeking to be acquired: On one hand, these firms could have the incentive to 'window dress', as Anilowski et al. (2009) point out, to attract a buyer. To the extent that current earnings signal potential for future profitability and cash flows, this gives an economic motive for upwards earnings 
management. On the other hand, an economic motive for downwards EM is that the resulting lower value of the 'seeking buyer' firm may actually facilitate the completion of a future deal, albeit at some cost for the shareholders. ${ }^{2}$ Easterwood (1998), Eddey and Taylor (1998) and Ben-Amar and Misisoner-Piera (2008) provide evidence of downwards EM by specific subsets of M\&A target firms. Moreover, Perry and Williams (1994) and Wu (1997) provide evidence of downward EM in the context of management buy outs (MBOs) in order to facilitate the deal, induce shareholders to accept lower prices, and also provide support for the fairness of the buyout price.

The two hypotheses expressed above are not equally plausible. Why should a potential target firm manage its earnings downward and thus achieve a lower acquisition price, when it could maintain its higher earnings and simply communicate its willingness to accept a lower price to possible bidders? Intuitively, one would expect a poor performing underpriced firm to be considered a less attractive acquisition candidate than a well performing underpriced firm. Therefore, for a given acquisition price, upwards EM by 'seeking buyer' firms should be optimal in order to attract a bidder, provided this is not discounted by the buyer. In this context, we consider the first hypothesis to be more economically plausible than the second one and examine (a) whether on average firms seeking acquisition manage earnings and (b) the consequences of any earnings management practices by 'seeking buyer' firms (hereafter SB firms). This is in essence one of the contributions of this study when compared to the related work of Murdock and Madura (2011).

Using all U.S. non-financial listed firms that have issued a 'seeking buyer' announcement between 1990 and 2009, we first establish, in line with Murdock and Madura (2011), that these firms appear on average more levered and distressed, exhibit lower growth, are less liquid and slightly worse performing vis-à-vis matched firms according to size and industry.

\footnotetext{
${ }^{2}$ Of course whether shareholders are willing to accept this cost depends on what are the alternatives for 'seeking buyer' firms if an acquisition is not achieved after all.
} 
We investigate whether SB firms engage in EM practices in the year the announcement is made (and the years surrounding that), by calculating their discretionary accruals (hereafter DA) through a number of methods proposed in the literature, including controls for the influence of earnings performance on the estimation of accruals. However, certain firm characteristics that are especially pronounced in SB firms, specifically financial distress and firm growth, may interfere with the calculation of accruals. Evidence by McNichols (2000) indicates that firms with higher growth in earnings will have higher discretionary accruals, and DeAngelo et al. (1994) also find that troubled companies have large negative accruals, which are mechanically expected for firms experiencing losses, regardless of the accounting choices undertaken by managers. In such a case, DA estimates examined for the existence of EM among SB firms, may be influenced by performance characteristics rather than pure incentives to manage earnings. To overcome this problem, we calculate DA by explicitly controlling for these SB firm-characteristics (namely growth and distress) which could result in a possible correlated omitted variable problem in the measurement of DA. ${ }^{3}$

We find that firms seeking to be acquired engage, on average, in downwards EM in the fiscal year they announce their intention (year $t$ ), and in up to two years prior to the announcement. Even after explicitly controlling for growth and financial distress, we find statistically significant evidence of downwards earnings management in the year the 'seeking buyer' announcement is made.

We interpret the finding that DA by SB firms become statistically insignificant in years $t-1$ and $t$-2 upon implementing controls for growth and distress as indicative of growth and financial distress representing possibly omitted variables in the estimation of DA for these firms. In other words, these economic factors are overrepresented in the sample under examination, so require specific controls to ensure DA are not mis-measured. However, we

\footnotetext{
${ }^{3}$ This calculation actually involves making an ex ante hypothesis of an omitted variable in the measurement of accruals for this particular group of firms. This hypothesis is justifiable given the economic characteristics that appear overrepresented in this particular sample (low growth and distress), and assures our research design is not flawed by relevant omitted factors influencing accruals which are actually present but ignored.
} 
do report significant evidence of negative EM by SB firms in year $t$, even after controlling for growth and financial distress.

We feel that this evidence points towards SB firms exhibiting some type of 'big bath' behavior in the year they publicly announce their intention to be acquired. Our findings are consistent with the notion that SB firm managers choose to underreport bad news earnings as much as possible, to provide the potential for reporting significant improvements in profits in subsequent years (Christensen et al., 2008; Elliott and Hanna, 1996). This would allow the SB firm to make a 'fresh' new start or a 'turnaround', especially in the case a buyer is actually found. By cleansing financial statements in the year they publicize their intention to be acquired, the favourable resolution hypothesis further predicts positive returns, as this action may be received by market participants as a constructive response to existing problems, indicative of effective management (Elliott and Shaw, 1988). Positive abnormal stock returns around the SB announcement day are indeed reported later on our study (see also Murdock and Madura, 2011). According to Kirschenheiter and Melumad (2002), taking a big bath represents an equilibrium reporting strategy for sufficiently bad news, where the manager underreports earnings by the maximum, to report higher future earnings, which could be the case if the firm is eventually acquired free from burdens from bad news from the past. Such a reporting strategy is implied by our findings for the average SB firm.

We also provide evidence, using SB and matched firms, that discretionary accruals at the year of the SB announcement, or the year before that, negatively affect the possibility of a firm issuing such an announcement. This result is observed after implementing controls for other variables possibly able to affect the 'seeking buyer' decision (i.e. distress and growth), and also nondiscretionary earnings or 'expected' earnings (Healy, 1996). Less profitable, more distressed and smaller firms, and also firms with a smaller amount of outside blockholders in their stock ownership structure are found to be more prone to this observed EM behaviour among SB firms. This last finding could be an indication that these firms have fewer outside pressures to report good results. 
Moreover, we examine in this paper the consequences of earnings management by 'seeking buyer' firms. We first assess the impact of EM on SB firm stock returns around the SB announcement day, and also investigate whether the probability that a SB firm is eventually acquired is related to earnings management practices. We first find that SB firms exhibit positive and significant cumulative abnormal returns around the SB announcement day, especially for one or five-day event windows. This evidence, consistent with Murdock and Madura (2011), implies that SB announcements are received as positive news by market participants. This suggests that market participants believe that the management makes the best business choice for the firm at this particular point of time. After controlling for a number of factors with a possible influence on returns, including growth, firm size, performance and nondiscretionary earnings, we find that discretionary accruals positively relate to abnormal market performance around SB announcement, i.e. 'window dressing' tactics are positively priced by the market. Evidence on a positive association between DA and market performance is consistent with previous findings outside of the SB context (Guay et al., 1996; Subramanyam, 1996). In the case of SB firms, this provides an indication that market participants reward these SB firms which do not actually engage in any 'big bath' behaviour in relation to the announcement. To the extent that 'big bath' behaviour is indicative of a firm seeking an acquisition for performance-related reasons, this constitutes evidence that the market does not positively receive and price this motivation for SB.

At a final stage, we find that positive EM actually improves the possibility for a SB firm to secure an acquisition within a reasonable period after the relevant announcement. Since SB firms are found to perform downwards EM on average, and since a significant proportion of SB announcements are motivated by operating performance (Murdoch and Madura, 2011), our results suggest that the firms eventually acquired are the ones that abstain from 'big bath' practices, possibly because their motivation for 'seeking a buyer' is not performance-related. In other words, attractive acquisition targets are firms which do not exhibit the average 
behaviour of a firm SB, and could be actually stronger than average operationally, a fact that is compensated for by a potential bidder.

Besides the contribution this study makes in relation to a rather unusual corporate announcement that has not been extensively investigated in the literature, our work is also related to studies that examine earnings management in the context of specific subgroups of possible target firms, and contributes to our understanding of the motives behind EM by firms involved in M\&As. As previous findings on EM for targets have been context-dependent, we examine EM in another context which is unique in nature, since it focuses on M\&A target firms which have both the time and an opportunity to influence earnings in order to affect contractual outcomes. In this respect, we find that on average, these firms prefer to take all the steps necessary to allow them to make a fresh new start i.e. underreport earnings by the maximum, anticipating that their future course could be improved upon achieving their goal in terms of finding an acquirer. Overall our paper, by highlighting the M\&A market consequences of EM for target firms openly acting as deal initiators, works towards providing a better understanding of the impact of EM on the facilitation of business transformations.

The rest of the study is organized as follows: In Section 2, we present in more detail the related literature which provides motive for this study. In Section 3, the sample selection process and methodology are presented. In Section 4 we examine whether 'seeking buyer' firms manage their earnings, while Section 5 is dedicated to assessing the impact of earnings management on the decision to issue a 'seeking buyer' announcement and on the subsequent acquisition outcome. Section 6 concludes the paper.

\section{Related Literature and Motivation}

Seller-initiated takeovers are unusual corporate events, which raises the question of what is unique or different about these firms which decide to openly issue such a 'seeking buyer' statement. Providing an answer on why firms which want to be acquired declare this intention publicly goes beyond the scope of this paper. The purpose of this study is rather to examine 
whether these firms engage in EM, as these firms have both motivation and opportunity to engage in such actions.

However, under the expectation that these SB events are non-random, one could argue that distinct economic features of SB firms might cause omitted variable issues in detecting EM. In other words, could it be that distinct features of SB firms are fundamental, with respect to modelling subsequent accounting choices?

Regarding the characteristics and motives of SB firms, existing research is very limited, with the exception of Murdock and Madura (2011), who report that firms SB tend to be characterized by lower Altman's (1968) Z scores, larger size, lower growth, and more homogeneous business focus. These characteristics vary greatly between them and can be conceptually contradictive as well, since, for example, a larger firm could be expected to face fewer capital constraints and thus, be less financially distressed. To the extent that these traits provide no uniform nature of firms SB, we would not expect distinct characteristics of firms SB to be at the root of possible directional earnings manipulation around the event.

However, two of the operational characteristics mentioned above, exceptionally poor operating performance or financial distress and firm growth, may interfere with the calculation of accruals (McNichols, 2000; DeAngelo et al., 1994 for troubled firms). As McNichols (2000) points out, earnings management tests require that measurement error in the discretionary accrual proxy is uncorrelated with the partitioning variable in the research design in order for the test to be unbiased. This is because hypothesized determinants of earnings management, in case they are correlated with economic characteristics that may influence nondiscretionary accruals, will result in mis-specified EM tests, if these tests do not control for these correlated determinants of nondiscretionary accruals (Dechow et al, 2012).

McNichols (2000) finds that without any explicit partitioning on an incentive variable, firms with higher growth in earnings will have higher discretionary accruals. This is because accruals represent changes in working capital accounts, so one would expect rapidly growing 
firms to experience larger accruals (McNichols, 2000). DeAngelo et al. (1994) also find that troubled companies have large negative accruals, which are the mechanical thing to expect for firms experiencing losses, regardless of the accounting choices undertaken by managers: This is because low accrual realizations will tend to map into low earnings realizations (DeAngelo et al., 1994). Peltier (1999) additionally finds that troubled firms have large negative accruals.

In such a case, discretionary accruals (DA) estimates of SB firms may be influenced by performance characteristics rather than pure incentives to manage earnings. To overcome this problem, we calculate DA by explicitly controlling for these SB firms possible characteristics which could result in a possible correlated omitted variable problem in the measurement of DA. In specific, we control our DA estimates for profitability, growth and financial distress using a number of proxies suggested in the literature (ROA, change in ROA, Tobin's Q, Altman's Z-score, etc.) in order to ameliorate concerns that these characteristics are the explanatory variable of any observed DA, rather than EM.

As with the characteristics of SB firms, previous research has further observed a number of different motivations behind issuing a SB announcement. These include strategic reasons, leverage, growth, or distress (see Murdock and Madura, 2011). Although one could find arguments for and against EM behaviour, depending on the incentive valid each time, our scope is to examine whether firms openly seeking to find a buyer on average manage earnings, and in which direction.

A firm seeking to be acquired may have such a motivation for a number of reasons. Palepu (1986) identified a range of possible firm attributes which can make a firm a possible takeover target, which conceptually stem from the possible inability of the current management to maximize shareholder wealth. Once the decision to seek a buyer has been taken by management, the scope to attract a buyer could provide motivation to manage earnings in a way to facilitate achieving a deal. At this point, Erikson and Wang (1999) find evidence of positive (upwards) but not significant earnings management by target firms, in 
the quarter before deal announcement. This measurement, though, could be misleading, since EM is detected quite late in the deal process, raising questions on whether EM can be performed that late by targets (see the criticism by Ronen and Yaari, 2008). Christie and Zimmerman (1994) testify income increasing accounting choices by target firms. Easterwood (1998) distinguishes between friendly and hostile takeovers and detects upwards EM for targets engaging in hostile takeovers, but no income increasing tactics in targets being acquired in friendly bids.

Eddey and Taylor (1998) hypothesize in favour of positive EM for hostile bids, and income decreasing EM for target firms whose management has a positive attitude towards the transaction, in order to facilitate the bid. They do testify income decreasing tactics for firms whose management recommends bid acceptance, but observed negative unexpected accruals are not significantly different from zero.

Ben-Amar and Misisoner-Piera (2008) find evidence on income decreasing EM by friendly takeover targets for Swiss firms. They justify this practice as possibly resulting from the fact that in friendly transactions, the target directors may not be necessarily associated with significant strategic changes, as underlined by Healy et al. (1997). In an opposite case, were the takeover to occur within a hostile environment, the management of the target would have incentives to inflate earnings in order to make the deal more difficult to proceed. Target management in friendly takeovers may also want to decrease earnings in order to report better operating results post-acquisition. Ben-Amar and Misisoner-Piera (2008) also attribute negative EM by friendly takeover targets to the observations that control premiums tend to be smaller in friendly transaction as opposed to hostile bids (Healy et al., 1997), and high job retention chance by the target management post-merger.

Anilowski et al. (2009) relate EM by target firms to the method of sale (auction vs. negotiation), hypothesize in favour of 'window dressing' and find upward EM in firms being acquired via an auction as opposed to a negotiation. More recent studies relate targets' 
earnings quality to the form and outcome of the acquisition process (see McNichols and Stubben, 2012, Raman et al., 2009 and Marquardt and Zur, 2010). Although the notion of earnings management does not coincide with earnings quality, the two ideas are conceptually close, and highly managed earnings should be low quality earnings (Lo, 2008), in a sense that they do not signal true firm economic information, as they cave the scope to affect contractual outcomes (see the Healy and Wahlen, 1999, definition of EM).

Previous literature on EM by acquired firms assesses income increasing or decreasing practices ex post, once the transaction has occurred. If a firm that participates in a transaction has neither the time nor the opportunity to act in a way to affect the structure and economics of the deal, then this party should not be expected to engage in deal-related EM. In case an acquisition is bidder-initiated, this very fact deprives the target from both motivation and opportunity to act in a way as to influence its earnings to affect contractual outcomes However, 'seeking buyer' firms are essentially deal initiators, and are by no means passive parties in a subsequent transaction. This argument is in line with Erikson and Wang (1999), who conclude that EM is more likely in the case of acquiring firms than for targets, since bidders are aware of their intentions significant time before the acquisition.

We identify two possible motivations as to whether firms seeking a buyer should manage earnings. On one hand, they have the incentive to window dress in order to attract the greatest possible number of buyers and achieve a bid at the highest price. If earnings signal potential for future economic performance and cash flows, 'window dressing' signals that the firm constitutes a promising investment. On the other hand, from an opportunistic point of view, lower economic value, in the extent that this is achieved by downwards EM, makes a firm an easier takeover target, and thus this facilitates the pursuit of an acquirer and achieving the scope to be acquired. At the same time, in line with the Ben-Amar and Misisoner-Piera (2008) arguments, weaker pre-merger performance can give the opportunity to exhibit better results post-merger, if management retain their positions. However, we consider that the first motivation for upwards EM in order to attract a buyer is more economically plausible, in a 
sense that a well performing underpriced firm should be expected to be a more attractive target than a low performing overpriced firm. A well performing SB firm could keep its higher earnings and simply communicate its willingness to accept a lower price, instead of recurring to explicit downwards EM to make itself a more price attractive buyer. We therefore examine whether firms SB on average manage earnings, and investigate into the possible economic consequences of EM of firms SB by examining the impact of such EM on stock returns around the SB announcement, and also on the probability of finding a buyer within a reasonable amount of time from the announcement.

Although publicly issuing a SB announcement may naturally result in a subsequent friendly takeover, we view our work in this paper significantly different from testing for EM in targets of friendly takeovers for a number of reasons. First, by making such a statement instead of contacting possible bidders privately or through an investment bank, the firm might seem desperate, resulting in a lower premium being paid to target shareholders. Second, close to the arguments of Murdock and Madura (2011), openly 'seeking a buyer' is an unusual practice that might in theory attract or deter a possible acquirer, depending on whether a potential bidder sees this action as facilitative or not of a future bid process. In the case of friendly takeovers, relative motivations are expected to be less complex and more straightforward as a negotiation with a single bidder goes through after a certain point. Third, a friendly takeover can be very well unsolicited, while issuing SB announcements are clearly seller-initiated transactions, providing both motive and opportunity for EM. As Skaife and Wangerin (2012) point out, although targets, as well as acquirers, may have clear incentives to manage earnings before an acquisition, targets have difficulty to anticipate both if and when a bid will be received, which is not the case for SB firms. Thus, we posit that the empirical setting of this paper differs from examining earnings management by target firms in friendly takeovers (as in Easterwood,1998; Ben-Amar and Misisoner-Piera, 2008).

Anilowski et al. (2009) also test for EM in firms acquired via an auction as opposed to negotiation, i.e. firms that may have contacted possible bidders before a deal has taken place, 
which could have given them both the time and opportunity to affect financial statements in an opportunistic way. Our study, though, is different from Anilowski et al. (2009), as we do not test for EM ex-post, when a completed acquisition has taken place depending on the method of sale: we focus on firms openly seeking to be acquired, assess the different motivations for EM for these firms, and further track the impact of possible EM on their market performance, as well as their chances for securing an acquisition, depending on having engaged in EM or not. We view that the examination for possible EM in firms seeking buyer, as opposed to acquired firms ex-post, could improve the understanding of the motivation of target firms during the acquisition process, given that SB firms may constitute a unique and natural sample of possible target firms which have an active role in an acquisition deal. At the same time, this investigation could be helpful for bidders targeting firms which seek a buyer.

\section{Sample selection, descriptive statistics and methodology}

\subsection{Sample selection}

Data of all public U.S. firms that have issued a 'seeking buyer' announcement between 1990 and 2009 were downloaded from the Thomson One M\&A database. We focus only on publicly-listed SB firms due to data availability constraints.

Thomson One defines a 'Seeking Buyer'-SB announcement as a case where 'the target company has announced plans to seek out a buyer or buyers for its assets or the company itself'. For illustration purposes, we include two typical such SB announcements from our sample in Appendix A. Virtually all SB announcements in our sample period appear to be of the same phrasing; strategic considerations are highlighted as the main motive behind the decision to openly look for a merger or acquisition partner.

There are 368 such announcements by public U.S. firms in our sample period. Removing SB announcements by firms in the financial sectors (SIC codes in 6000s), as accruals and unexpected accruals are difficult to define for firms in these sectors (see Zhao and Chen, 
2008b), lowered the number to 313. Further requiring that there are data available in Compustat for the control variables employed in at least one of the models used to detect earnings management (models are outlined in the next subsection) brings the final number of 'seeking buyer' announcements to 248 firms.

Figure 1 plots the number of firms seeking a buyer per year between 1990 and 2009. Announcements per year vary from 6 in 2004 to 22 in 1991. SB announcements appear to be more heavily concentrated in years 1990-1991, 1994-1995 (17 announcements for both years), 1998, 2002 (17 and 15 announcements, respectively), and to pick up again in year 2009 with 17 firms SB. Overall, announcement waves appear to have a slight co movement with the economic cycle.

Regarding the industry sectors to which SB firms belong, Figure 2 presents information on the 2 digit SIC codes of the 248 sample firms. As one observes from Figure 2, firms SB are more heavily concentrated within technology and services sectors. More specifically, SIC codes 73 (Business Services) and 36 (Electronic and Electrical Equipment and Components) are more heavily represented, with 24 and 19 SB firms respectively. Measuring, analyzing and controlling instruments (SIC code 38) and oil and gas extraction (SIC code 13) are also well represented, with 18 and 15 firms respectively. Regarding technology firms with SB announcements, both 'old' and 'new economy' sectors are represented, according to the Loughran and Ritter (2004) categorization of technology firms.

\section{Insert Figures 1 and 2 about here.}

\subsection{Descriptive statistics}

We report means and medians of key financial variables of all U.S. non-financial listed firms that have issued a 'seeking buyer' announcement between 1990 and 2009 in Table 1, for the fiscal year the 'seeking buyer' announcement is made (year $t$ ) and the two previous years. To save space, we relegate the definitions of all the financial variables reported in Table 1 to Appendix B. 
For comparison purposes, the corresponding means and medians of two matched samples are also reported in Table 1. To construct the matching firms' samples, each 'seeking buyer' firm is matched in year $t$ with two firms from the same 4-digit SIC code, based on their market capitalization (the Matching firms-MVE sample), or with two firms from the same 4-digit SIC code based on their total assets (the Matching firms-TA sample). Our matching procedure is similar to the one in Hasbrouck (1985) and Murdock and Madura (2011). ${ }^{4}$

The median firm that issues a 'seeking buyer' announcement appears significantly larger in size that the corresponding $M V E$-matched sample firm in all years leading to the announcement, without however any consistent difference in sales achieved. The median (mean) SB firm achieves positive (negative) profitability ratios in all years leading to the announcement year and it appears significantly less profitable than matched firms. On the other hand, there is virtually no statistically significant difference in terms of operating performance (CFO/TA, R\&D/TA, etc.), or growth in terms of Market-to-Book or Tobin's $\mathrm{Q}$ between SB firms and their 'equal-size' industry peers.

However, SB firms are observed to exhibit significantly lower (median and sometimes mean) liquidity than matched firms for the examined period (in terms of both the current and the quick ratio), and slightly higher leverage (at least in comparison with the $M V E$-matched sample). As far as other growth proxies are concerned (SGR, $\triangle \mathrm{ROA}$ ), SB firms are found to have significantly lower growth in sales for year $t$ (but not in previous years) and also lower change in ROA (using median values and matching by $T A$ ). Moreover, regardless of the matched sample used, SB firms exhibit significantly lower Altman Z scores in all years leading to the announcement, suggesting these firms might be more distressed than their 'equal-size' industry peers. This is in line with Murdock and Madura (2011), who find that SB firms tend to be more financially distressed.

\footnotetext{
${ }^{4}$ Ecker et al. (2011) underline the necessity to control for firm size in studies related to EM, as size is likely to be correlated with factors which could possibly affect accruals (e.g. growth, complexity and monitoring). Their findings indicate that lagged total assets constitute the most reliable proxy for firm size. However, for reasons of comparability of our results with Murdock and Madura (2011), we perform matching by contemporaneous total assets, and also use market capitalization, MVE, as an alternative size proxy.
} 
Overall, descriptive statistics from Table 1 seem to indicate that SB firms tend to be slightly less profitable compared to firms of comparable size from the same industry, exhibit lower Altman's Z scores, lower liquidity, higher debt ratios, and lower growth. Of course, the conclusions that can be drawn from Table 1 regarding SB firms are rather limited, given the univariate dimension of the comparisons; however the Table does provide an imperfect indication of the 'average-median' profile of firms that engage in such an unusual corporate event that has not been extensively studied in the literature, and it should be read with the above limitation in mind.

Insert Table 1 about here.

\subsection{Estimating earnings management}

Earnings management can occur by structuring transactions towards achieving a desired financial statement output, by deviating from 'normal business practices, undertaken with the primary objective of meeting certain earnings thresholds' (Roychowdhury, 2006), or through the management of firm accruals, which arise upon discrepancies 'between the timing of cash flows and the timing of the accounting recognition of income' (Ronen and Yaari, 2008).

Following previous literature (indicatively Erikson and Wang, 1999; Zhao and Chen, 2008a, 2008b; Anilowski et al., 2009), we test for possible EM in SB firms by examining the statistical significance of firm discretionary accruals two years before and one year after a firm seeks a buyer, as well as in the event year (the year the firm announced its intention to be acquired). Much like in previous event study research on EM (e.g. Perry and Williams, 1994), we consider the $[t-2, t]$ to be a time window allowing a firm which SB to engage in actions which could help achieve specific goals, and we follow EM detection for up to year $t+1$, given that a firm is not expected to be acquired immediately from the moment it declares itself as 'seeking a buyer'. 
The literature has established that prevailing techniques for the detection of EM through the isolation of the discretionary component of accruals are often biased (Kothari et al., 2005) or suffer from misspecification errors and lack statistical power (Dechow et al., 1995, Dechow et al., 2012). At the same time, our sample of firms is by construction non-random in nature, given that it consists of firms seeking to participate in a distinct corporate event, and could thus have motivation to alter their level of accruals, which is in turn used for EM detection. To account for these issues, we make use of a large number of different model specifications in order to assess the significance of non discretionary accruals for SB firms.

Specifically, we make use of the following approaches (with some modifications with respect to the definition of variables)

\section{Model 1: Jones Model (Jones, 1991)}

We first estimate cross-sectionally the following regression for all years according to 2-digit SIC codes:

$$
\mathrm{TAcc}_{i, t} / \mathrm{TA}_{i, t-1}=a_{0}+a_{1} / \mathrm{TA}_{i, t-1}+a_{2} \Delta \operatorname{Rev}_{i, t} / \mathrm{TA}_{i, t-1}+a_{3} \mathrm{PPE}_{i, t} / \mathrm{TA}_{i, t-1}+\varepsilon_{i, t}
$$

where (Compustat item number in parentheses):

TAcc $_{i, t}=$ firm $i$ 's Total Accruals calculated from the Cash Flow Statement in year $t$, defined as $\mathrm{NIBE}_{i, t}-\mathrm{CFO}_{i, t}$;

$\mathrm{NIBE}_{i, t}=$ firm $i$ 's Net Income Before Extraordinary items (\#123) in year $t$;

$\mathrm{CFO}_{i, t}=$ firm $i$ 's Cash Flows from Operations (\#308) in year $t$;

$\mathrm{TA}_{i, t-1}=$ firm $i$ 's Total Assets (\#6) at the end of year $t-1$;

$\Delta \operatorname{Rev}_{i, t}=$ firm $i$ 's change in Revenues (\#12) between year $t-1$ and year $t$;

$\operatorname{PPE}_{i, t}=$ firm $i$ 's gross value of Property, Plant and Equipment (\#7) in year $t ;$

$\varepsilon_{i, t} \quad=$ error term.

We then use the industry- and year-specific parameter estimates $\hat{a}_{0}, \hat{a}_{1}, \hat{a}_{2}$ and $\hat{a}_{3}$ to infer firm-specific discretionary accruals (DA): 
$\mathrm{DA}_{i, t}=\mathrm{TAcc}_{i, t} / \mathrm{TA}_{i, t-1}-\hat{a}_{0}-\hat{a}_{1} / \mathrm{TA}_{i, t-1}-\hat{a}_{2} \Delta \operatorname{Rev}_{i, t} / \mathrm{TA}_{i, t-1}-\hat{a}_{3} \mathrm{PPE}_{i, t} / \mathrm{TA}_{i, t-1}$

\section{Model 2: Modified Jones Model (Dechow et al., 1995)}

We first estimate cross-sectionally the following regression for all years according to 2-digit SIC codes:

$\mathrm{TAcc}_{i, t} / \mathrm{TA}_{i, t-1}=a_{0}+a_{1} / \mathrm{TA}_{i, t-1}+a_{2} \Delta \mathrm{Rev}_{i, t}-\Delta \mathrm{AR}_{i, t} / \mathrm{TA}_{i, t-1}+a_{3} \mathrm{PPE}_{i, t} / \mathrm{TA}_{i, t-1}+\varepsilon_{i, t}$

where all variables as before, and

$\Delta \mathrm{AR}_{i, t}=$ firm $i$ 's change in Accounts Receivable (\#2) between year $t-1$ and year $t$.

We then use the industry- and year-specific estimates parameter estimates $\hat{a}_{0}, \hat{a}_{1}, \hat{a}_{2}$ and $\hat{a}_{3}$ to infer discretionary accruals (DA) as in Model 1, with an equation similar to (1). In this model, following Kothari et al. (2005), DeFond and Park (1997) and Subramanyam (1996), we subtract the change in accounts receivable from the change in revenues before estimation.

\section{Model 3: Ball and Shivakumar (2006) approach}

We first estimate cross-sectionally the following regression for all years according to 2-digit SIC codes:

$\mathrm{TAcc}_{i, t} / \mathrm{TA}_{i, t-1}=a_{0}+a_{1} / \mathrm{TA}_{i, t-1}+a_{2} \Delta \operatorname{Rev}_{i, t} / \mathrm{TA}_{i, t-1}+a_{3} \mathrm{PPE}_{i, t} / \mathrm{TA}_{i, t-1}$

$$
+a_{4} \mathrm{CFO}_{i, t} / \mathrm{TA}_{i, t-1}+a_{5} 1_{\mathrm{CFO}_{i, t}<0}+a_{6} 1_{\mathrm{CFO}_{i, t}<0} \times \mathrm{CFO}_{i, t} / \mathrm{TA}_{i, t-1}+\varepsilon_{i, t}
$$

where all variables as before, and

$1_{x}=$ a dummy variable taking the value of one if condition $x$ is true, and zero otherwise.

We then use the industry- and year-specific parameter estimates $\hat{a}_{0}, \hat{a}_{1}, \hat{a}_{2}, \hat{a}_{3}, \hat{a}_{4}, \hat{a}_{5}$ and $\hat{a}_{6}$ to infer discretionary accruals (DA) as in Models 1 and 2 with an equation similar to (1). The exact computational procedure for this model follows from Prevost et al. (2008). 


\section{Model 4: ROA-adjusted Model (Kothari et al., 2005)}

We calculate performance-adjusted discretionary accruals by making use of ROA-matched portfolios, as in Zhao and Chen (2008). We divide sample firms into deciles for each SIC code separately. These deciles are based on the current year ROA for every firm (see Appendix $\mathrm{B}$ for the calculation of ROA). Performance-adjusted abnormal accruals are calculated as the difference between the discretionary accruals for a firm and the median discretionary accruals of firms in the same year/industry ROA decile:

$$
\text { DA Performance Matched }{ }_{i, t}=\mathrm{DA}_{i, t}-\text { IndMedianDA }_{i, t}
$$

where all variables as before, and:

$$
\begin{aligned}
\mathrm{DA}_{i, t}= & \begin{array}{l}
\text { firm } i \text { 's Discretionary accruals, calculated via Model } 2 \text { above } \\
\text { (Modified Jones) }
\end{array} \\
\text { IndMedianDA }_{i, t}= & \begin{array}{l}
\text { Median abnormal accruals for firm } i \text { 's industry ROA decile, } \\
\text { excluding firm } i .
\end{array}
\end{aligned}
$$

\section{Models 1a -1b, 2a-2b, 3a-3b: Growth-adjusted and Distress-adjusted Models}

We calculate fifteen variations of Models 1, 2 and 3 above, using the portfolio-matching approach of Model 4. Given the economic characteristics (lower growth and Z-scores, etc.) of our 'seeking buyer' firm sample, highlighted in Table 1 of Section 3.2, and the findings of Murdock and Madura (2011) that SB firms are financially distressed, we calculate growthadjusted and distress-adjusted discretionary accruals by making use of matched portfolios that are created on a number of growth and distress proxies.

Growth and distress-adjusted abnormal accruals are again calculated through equation (2), only now $\mathrm{DA}_{i, t}$ is calculated from Models 1, 2 and 3, and IndMedianDA ${ }_{i, t}$ is the median abnormal accruals for firm $i$ 's industry decile, where the deciles are created based on a growth or distress proxy. The proxies we employ for constructing the portfolio deciles are: the change in ROA ( $\triangle$ ROA-matched Models 1a, 2a, 3a), Altman's Z-score (Z score-matched Models 1b, 2b, 3b), Tobin's Q (Q-matched Models 1c, 2c, 3c), Sales growth (SGR-matched Models 1d, 2d, 3d) and Market-to-Book (MB-matched Models 1e, 2e, 3e). Appendix B 
provides definitions for the calculation of the proxies. For reasons of economy of space, we only report results for models $1 \mathrm{a}-1 \mathrm{~b}, 2 \mathrm{a}-2 \mathrm{~b}, 3 \mathrm{a}-3 \mathrm{~b}$ in the paper.

Before leaving this section, a few notes regarding the estimation of the above models are in order. First, before estimation all observations are truncated at percentiles $1 \%$ and $99 \%$, and we further remove observations with an absolute value of total accruals greater than one following Kothari et al. (2005). Secondly, we impose a minimum of 20 observations in each annual, cross-sectional regression of same 2-digit SIC code firms, as in Francis et al. (2005) and Zhao and Chen (2008b). Regarding the use of a true constant term in the regressions (other than the term of a constant scaled by lagged total assets), we follow Kothari et al. (2005) and include one in the results reported, following arguments that such an inclusion constitutes an additional control for heteroskedasticity, mitigates problems arising from an omitted size variable, and may result in more symmetric discretionary accrual calculation, thus increasing test power. Other studies, e.g. Ball and Shivakumar (2006) and Zhao and Chen (2008b), do not use a true constant term in the regressions. Replicating the analysis without an intercept in regressions provides qualitatively similar (and in most cases stronger) results (available upon request). Finally, using different (not reported in this version of the paper) approaches for the definition of accruals (i.e. total accruals calculated from the balance sheet or working capital accruals as in Dechow and Dichev, 2002, and Guay, 2006) does not alter the direction of results.

\section{Empirical findings: Do 'seeking buyer' firms manage earnings?}

\subsection{Earnings management in firms seeking a buyer}

For the sample of U.S. non-financial listed firms that have publicly announced an intention to be acquired between 1990 and 2009, Table 2 reports averages, medians and standard deviations of discretionary accruals calculated from Models 1-4 (Panel A), as well as for a selection of the growth and distress-adjusted alternatives ( $\mathrm{Z}$ score and $\triangle \mathrm{ROA}$ adjusted - Panel B). Results are reported for as early as two fiscal years before the year of the SB 
announcement (year $t$ ), up to and including one fiscal year after that; statistical significance of means and medians is assessed through standard, two-tailed $t$-tests and two-tailed Wilcoxon signed-rank tests respectively. ${ }^{5}$

Insert Table 2 about here.

In Panel A, all four models indicate negative and statistically significant mean discretionary accruals at the $5 \%$ or $1 \%$ significance level in the announcement year. Interestingly, this holds for years $t-1$ and $t-2$ as well, for Models 1-3, all of which indicate significantly negative mean accruals. Model 4 points towards significantly negative DA for year $t-1$ at $10 \%$, but not for year $\mathrm{t}-2$. Results are mixed for year $t+1$, for which only the Jones and Modified Jones models, indicate the existence of negative EM. Median accruals are negative and statistically significant for all but the performance-adjusted Model 3 models in year $t-1$, and the Modified Jones and Ball and Shivakumar (2006) specification in year $t$. Overall, results from Panel A show that mean and median discretionary accruals appear to be overwhelmingly negative, although not always significant, pointing towards the existence of negative EM, even after adjusting accruals for performance.

Statistical significance of DA for the years leading to the 'seeking buyer' announcement seems to disappear in Panel B. However, even after adjusting for growth and distress in Panel $\mathrm{B}$, there appears to be strong evidence of statistically significant negative EM on year $t$. The statistical significance remains strong when controlling for growth $(\triangle \mathrm{ROA})$, and slightly weakens when controlling for distress (Z-score). Expressing growth in terms of Tobin's Q, the market-to-book ratio or sales growth does not qualitatively change the direction of results.

\footnotetext{
${ }^{5} \mathrm{~A}$ valid question with respect to the time window selected for DA assessment is whether one expects SB firms to manage earnings for up to two years before the announcement. We do expect the most relevant examination years to be $t$ and $t-1$, however, we do not wish to deviate from methodologies employed for the detection of EM before an event e.g. Perry and Williams (1994) for MBOs. In addition, when we examine DA in year $t$ and $t+1$, there is naturally a selection bias as firms actually acquired in years $t$ and $t+l$ drop out of the sample. This is also visible in the number of obviations from Table 2 but is considered as an expected study limitation due to its very research design.
} 
Therefore, we get evidence of negative EM from Table 2 for years $t$ and $t-1$ with reference to the SB announcement, even after adjusting accruals for the impact of performance factors in their calculation. When explicitly controlling for a possible influence of distress and earnings growth in the estimation of accruals, this evidence is found to hold only for the event year.

We interpret this evidence as indicative of the existence of factors influencing the measurement of DA for this particular subgroup of SB firms due to their average economic characteristics: in case low growth and distress are firm conditions overrepresented in the SB firm group, then, weak growth and distress negatively affect DA estimated under accrual estimation methods not accounting for the impact of growth on DA. However, the statistical significance of negative DA for year $t$, even after controlling for growth and financial distress, points towards negative EM being practiced, on average, by SB firms for reasons that cannot be attributed to bad performance, low growth potential or financial distress. What motivates negative EM by SB firms on the announcement year is, we feel, the following: Given that SB firms seem low-growth and financially-distressed, and that the 'seeking buyer' announcement itself produces a positive reaction by investors in the stock market (see Murdock and Madura, 2011, whose findings in this respect we confirm later on in the study), we feel that these firms might decide to exhibit some type of 'big bath' behavior in the year of the announcement. Since the SB announcement is perceived by market participants as good news for these firms, and from then on a 'turnaround' might be hoped for by managers and owners (especially in the case a buyer is actually found), it is possible that SB firms, for sufficiently bad news, may decide to underreport bad news earnings in an effort to allow the firm to make a 'fresh' new start, free from past burdens of factors which had negatively affected performance. This strategy has been indeed considered to be an efficient management choice for sufficiently bad news (Kirschenheiter and Melumad, 2002).

To further investigate the strength of our statistical findings in Table 2, we perform a comparison of the discretionary accruals of 'seeking buyer' firms, with those of two matched samples. The matched samples are the ones used in producing Table 1 (Matching samples 
$M V E$ and $T A$ ) and the matching process is described in section 3.2. For these matched firms, we calculate discretionary accruals using the models outlined in the previous section and compare them, in Table 3, with those by SB firms.

In all models reported in Table 3, SB firms exhibit on average significantly lower discretionary accruals, in the announcement year, than their 'equal-size' industry peers. Means and medians DA for SB firms are significantly negative, while matched firms tend to exhibit positive DA in the majority of cases. In most cases the differences in means/medians are considerable in size. This distinct behaviour of DA for 'seeking buyer' and matched firms also holds for years [t-2,t-1], at least for models that do not account for growth and distress. Taken together, the results in Tables 2 and 3 indicate that SB firms seem to practice downwards EM on average, at least for the fiscal year the announcement is made, when compared to similar-size industry rivals, and even after controlling for their reported low growth and financial distress.

Insert Table 3 about here.

\subsection{Which 'seeking buyer' firms are more prone to engage in earnings management?}

Given the evidence on significant downwards EM by 'seeking buyer' firms provided in the previous section, we examine next which SB firms are more prone to EM. We investigate whether certain financial or governance characteristics make our SB firms more or less prone to engage in EM, by regressing DA of SB firms on a number of variables, including controls for corporate governance and auditors employed.

As far as controls are concerned, previous research has established that increased scrutiny from auditors has a significant (negative) effect on accrual-based EM (see Cohen and Zarowin, 2010). Moreover, institutional investors with substantial share holdings in a firm's ownership structure may make it more difficult for the firm to manage earnings, given the higher level of sophistication of such investors. In addition, the existence of significant 'blockholders' has been found to positively affect discretionary accruals for firms facing 
declines in pre-managed earnings, since blockholders require higher returns from the firm (Zhong et al., 2007). A contradicting hypothesis with respect to the previous result would be that outside blockholders have stronger motivation and abilities to monitor the actions of firm management, so their presence might reduce within-GAAP earnings management through closer monitoring (Zhong et al., 2007).

We gather stock ownership and audit data for our sample of U.S. non-financial, listed 'seeking-buyer' firms from Thomson One and Compustat, respectively. The stock ownership of institutional investors and 'blockholders' is recorded, as a percentage of the total number of shares outstanding, as of the quarter-end immediately preceding the 'seeking buyer' announcement day (not year). The quarter immediately before the SB announcement, our 248 sample firms exhibited a mean of $44.52 \%$ ( $43.60 \%$ median) of shares outstanding owned by institutional shareholders, while on average, $23.81 \%$ of their shares (median: $19.00 \%$ ) were owned by outside blockholders at that point in time.

We estimate the following equation using OLS for the pooled SB sample during 1990-2009:

$$
\begin{gathered}
D A_{i}=\beta_{0}+\beta_{1} \operatorname{Lev}_{i}+\beta_{2} \operatorname{Ln}\left(T A_{i}\right)+\beta_{3} S G R_{i}+\beta_{4} Z_{i}+\beta_{5}\left(\frac{E B I T_{i}}{T A_{i}}\right)+\beta_{6} I N S T_{i}+\beta_{7} \text { BLOCK }_{i} \\
+\beta_{8} B I G 4_{i}+\beta_{9} \text { NonDE }_{i}+u_{i}
\end{gathered}
$$

where

$D A_{i} \quad=\quad$ Firm $i$ 's discretionary accruals in year $t$ (announcement year), estimated by all the models outlined in section 3.3;

$I N S T_{i}=$ Firm $i$ 's percentage of shares outstanding held by institutional investors the quarter-end immediately preceding the announcement day;

$B{ }^{\prime} O C K_{i}=$ Firm $i$ 's total percentage of shares outstanding held by all investors with an interest of at least $5 \%$ or greater, the quarter-end immediately preceding the announcement day;

$B I G 4_{i}=$ A dummy variable equal to one if the auditor of firm $i$ in year $t$ is a 'big 4' firm, and zero otherwise, and

$N_{o n D E}=$ Firm $i$ 's nondiscretionary earnings in year $t$. They are equal to operating cash flows plus nondiscretionary accruals (Hribar and Collins, 2002), where 
the latter are estimated by all the models outlined in section 3.3 (and they depend on which model is chosen for the dependent variable),

and all other variables as before (see Appendix B for definitions).

We follow previous research on the impact of EM on market performance (Subramanyam, 1996, Guay et al. 1996) and include nondiscretionary earnings in the above regression, in order to examine whether management of SB firms has exercised discretion over accruals conditional on nondiscretionary earnings (see Bartov et al., 2000). We report the regression estimation results in Table 4, for $D A_{i}$ estimated by Models 1 to 4 (other models available upon request). When the dependent variable $D A_{i}$ is estimated via the ROA-matched model of Kothari et al. (2005), we exclude $\left(E B I T_{i} / T A_{i}\right)$ from the right-hand side of the equation, to avoid imposing double controls for performance.

Apparently, there is a strong negative association between $D A_{i}$ and $N o n D E_{i}$, regardless of the model used to calculate the accruals. This is broadly consistent with McCulloch (1998) that documents a negative correlation between discretionary and nondiscretionary accruals. For all of the Jones (1991), Modified Jones, and Ball and Shivakumar (2006) models, profitability and Z-scores are found to positively affect DA confirming the need to control for these variables in our empirical design. This implies that our SB firms, which on average exhibit significantly negative DA, should be less profitable and possibly more distressed firms.

The ROA-matched DA alternative confirms a positive relation between $\mathrm{Z}$ score and DA, but also firm size and DA. Interestingly, for this model, we find a positive association (albeit at $10 \%$ ) between shareholdings owned by blockholders and DA, which implies that our SB firms that engage in downwards EM should be expected to have fewer blockholders, or not receive as much pressure to satisfy possible demands from them for good operating results. Overall, findings from Table 4 indicate that among the sample of SB firms, less profitable firms, which are also distressed and possibly smaller in size appear more prone to engage in downwards EM, while there is some evidence that a lower amount of blockholders may be associated with negative EM. 


\section{The impact of earnings management on the decision to issue a 'seeking buyer' announcement and on the subsequent acquisition outcome}

Given the evidence that 'seeking buyer' firms exhibit significantly negative discretionary accruals, at least in the fiscal year of their relevant public announcement, a key question we address in this paper is whether the decision to proceed to such an announcement---as well as the outcome of this action---is related to earnings management. We have argued that these firms have time and motive to engage in earnings management, provided evidence that on average they do (distinctly more than samples of matched firms), and wish to test whether this behaviour affects the decision and the outcome of making such an announcement. This is what we proceed to in this section.

\subsection{Earnings management and the decision to publicly seek a buyer}

We estimate the impact of EM on the decision of a firm to publicly seek a buyer. To accomplish this, we create two samples, one consisting of the union of SB firms with the 'Matching sample-TA' and the other from the union of SB firms with the 'Matching sample$M V E^{\prime}$ (see section 3.2 for the matching procedure).

Using each united sample, we estimate the following logit pooled regression,

$$
\begin{aligned}
S B_{i}= & \gamma_{0}+\gamma_{1}\left(W C_{i} / T A_{i}\right)+\gamma_{2}\left(R E_{i} / T A_{i}\right)+\gamma_{3}\left(E B I T_{i} / T A_{i}\right)+\gamma_{4}\left(M V E_{i} / T L_{i}\right)+ \\
& \gamma_{5}\left(S A L E S_{i} / T A_{i}\right)+\gamma_{6} \Delta R O A_{i}+\gamma_{7} \operatorname{Ln}\left(T A_{i}\right)+\gamma_{8} D A_{i}+\gamma_{9} N o n D E_{i}+\varepsilon_{\iota}
\end{aligned}
$$

where

$S B_{i} \quad=\quad$ A dummy variable that takes the value of one if firm $i$ in the union sample has issued a public 'seeking buyer' announcement between 1990 and 2009, and zero otherwise;

$D A_{i} \quad=\quad$ Firm $i$ 's discretionary accruals in year $t$ (announcement year) or year $t-1$, estimated by all the models outlined in section 3.3;

$W C_{i} / T A_{i}=$ Firm $i$ 's working capital over total assets in year $t(\# 179 / \# 6)$; 
$R E_{i} / T A_{i}=$ Firm $i$ 's retained earnings over total assets in year $t(\# 36 / \# 6) ;$

$M V E_{i} / T L_{i}=$ Firm $i$ 's market value of equity over total liabilities in year $t\left(\# 199^{*} \# 25 / \# 181\right)$

and all other variables as before (see also Appendix B for definitions).

Our treatment here is comparable to Murdoch and Madura (2011), only we explicitly control for the impact of earnings management on the decision to 'seek a buyer' by including discretionary accruals (DA). ${ }^{6}$ Following their lead, we explicitly control for size $\left(\operatorname{LnT} A_{i}\right)$, distress (via the $W C_{i} / T A_{i}, R E_{i} / T A_{i}, E B I T_{i} / T A_{i}$ - also a control for profitability - $M V E_{i} / T L_{i}$ and $S A L E S_{i} / T A_{i}$ components of Altman's Z-score) and growth (via the growth proxy $\triangle R O A_{i}$ that is least correlated with $M V E_{i} / T L_{i}$ ) in equation (3), and include the $D A_{i}$ variable that is the focus in our investigation. The $N o n D E_{i}$ variable controls for nondiscretionary earnings.

We use the discretionary accruals (adjusted and unadjusted) from all the models outlined in section 3.3 as independent variables, and summarize estimation results in Table 5. Note that we estimate (3) by taking $D A_{i}$ (and consequently $N o n D E_{i}$ ) as of year $t$ and, alternatively, $t-1$, to account for the impact of EM in the year of the announcement, or the year before, on the decision to SB.

Insert Table 5 about here.

In Panel A (respectively B) of Table 5, nondiscretionary earnings are included in (excluded from) the right-hand side. We observe from Table 5 that regardless of the inclusion of $N o n D E_{i}$ in the model, and regardless of whether year $t$ or $t-1$ discretionary accruals are used, there is a strong negative association between modified Jones $D A_{i}$ and the possibility of issuing a 'seeking buyer' announcement. Unfortunately, this finding is not robust to all possible models of $D A_{i}$ estimation: for example, the performance-adjusted ROA-matched accruals of Kothari et al. (2005) yield insignificant slope coefficients in Table 5, while the

\footnotetext{
${ }^{6}$ In their investigation, Murdoch and Madura (2011) include Altman's Z score as a regressor. However, given that operating performance or its changes may be at the root of a possible decision to SB, and at the same time it may interfere with the estimation of accruals, to overcome the problem that accounting performance also appears in $\mathrm{Z}$ score, we replace this score with the individual variables used in creating it, given that the focus of our study is on EM.
} 
growth-adjusted $\triangle \mathrm{ROA}$-matched and the distress-adjusted Altman $\mathrm{Z}$ score-matched accruals yield significantly negative coefficients (these are reported in Table C.1 of Appendix C to save space).

Overall, the estimation results in Tables 5 and C.1 provide some weak support for the claim that DA negatively relate to the SB decision, even after implementing controls for performance, financial distress and growth, suggesting that firms which issue 'seeking buyer' announcements tend to exhibit lower discretionary accruals, even after controlling for factors with a possible power to affect the decision. This is in line with the findings in Tables 2 and 3.

\subsection{Impact of earnings management on market performance around the 'seeking buyer' announcement day}

Our next step is to examine the consequences of possible EM by firms publicly seeking a buyer. We examine such consequences in terms of (a) the impact of possible EM on market abnormal returns around the announcement day, and (b) the impact of EM on the possibility that a SB is actually acquired within a reasonable amount of time from the moment the announcement was issued.

As far as the former is concerned, we first follow the standard 'event study' methodology to estimate cumulative abnormal stock returns over $[-k,+k]$ days around the announcement day (day 0) for each 'seeking buyer' firm (the 'event period'). All return data for this section are downloaded from CRSP. Using daily returns $[-l,-31]$ days before the announcement as the 'estimation period', we perform market model regressions

$$
R_{i, t}=a_{i}+b_{i} R_{m, t}
$$

for each SB firm $i$, where $R_{i, t}$ is the return of SB firm $i$ on day $t$ and the return of the valueweighted or equal-weighted CRSP market index on day $t$ is used as the market proxy $m$. Given estimates $\hat{a}_{i}, \hat{b}_{i}$ for each SB firm in the estimation period, we calculate firm $i$ abnormal returns $\left(A R_{i}\right)$ and cumulative abnormal returns $\left(C A R_{i}\right)$ via 


$$
A R_{i, t}=R_{i, t}-\left(\hat{a}_{i}+\hat{b}_{i} R_{m, t}\right) \quad \text { and } \quad C A R_{i}^{-k,+k}=\sum_{t=-k}^{+k} A R_{i, t}
$$

We report average cumulative abnormal returns, $A C A R^{-k,+k}=\frac{1}{N} \sum_{i=1}^{N} C A R_{i}^{-k,+k}$ across all SB firms in Table 6 , for a number of choices among $k=0,1,5,10$ and $l=240,340$. The statistical significance of ACAR is assessed by the standardized cross-sectional z statistic (SCS z-stat) of Boehmer et al. (1991), which accounts for event-induced changes in return variance. $^{7}$

Insert Table 6 about here.

Consistent with the results of Murdock and Madura (2011), we find that SB announcements are positively received by market participants. Statistically significant positive cumulative abnormal returns ranging from $0.69 \%$ to $2.83 \%$, depending on the market proxy and the estimation period, are found for $[-5,0],[-5,+5],[-1,0]$ and $[-1,+1]$ days around the announcement date. Results are robust to different estimation windows (e.g. $l=$ 140 in untabulated results) or market proxies and are unaffected by experimentations with other versions of the market model in equation (4) (i.e. adjusted market model, Scholes and Williams (1977) market model, etc.).

Overall, the evidence in Table 6 provides indications, in line with Murdock and Madura (2011) that SB announcements are viewed as positive events by the market, or that market participants appreciate the effort made by the management of such firms to positively affect the strategic course of the firm by finding a buyer and securing an acquisition.

The calculation of CAR is an intermediate step in our examination of the impact of possible EM on market abnormal returns around the SB announcement day. To this end, we regress CAR on discretionary accruals and a number of controls (following Murdock and Madura 2011):

\footnotetext{
${ }^{7}$ Higgins and Peterson (1998), among others, advocate the use of standardized cross-sectional (SCS) test statistics in event studies, to account for event-induced changes in return variance and nonnormality of returns. The SCS z-statistic is nowadays routinely reported by 'event-study' dedicated software (e.g. Eventus).
} 


$$
\begin{gathered}
C A R_{i}=\delta_{0}+\delta_{1} \operatorname{Lev}_{i}+\delta_{2} \operatorname{Ln}\left(T A_{i}\right)+\delta_{3} Q_{i}+\delta_{4} Z_{i}+\delta_{5}\left(E B I T_{i} / T A_{i}\right)+\delta_{6} D A_{i}+ \\
\delta_{7} N_{o n D E}+e_{i}
\end{gathered}
$$

with $L e v_{i}$ the leverage of firm $i$, defined as total debt over total assets and all other variables as before. We are interested in the effect of $D A_{i}$ on abnormal returns, after accounting for size, growth, financial distress, profitability and 'unmanaged' income.

There is a variety of alternative specifications of equation (5), depending on the model used to estimate $D A_{i}$ and $N o n D E_{i}$, the length of the estimation and event periods in $C A R_{i}$ calculation, the market proxy used, etc. There is also a dilemma among using $D A_{i}$ and $N o n D E_{i}$ as of the announcement year or the one before that, as the financial statements of year $t$ may not be public information on the announcement day where $C A R_{i}$ is calculated. The same dilemma might apply to the control variables.

To save space, we summarize in Table 7 the estimation results for a number of alternative specifications by making a few choices, relegate the results of another set of choices in Appendix D and make all other results available upon request. In Table 7 (Table D.1), $D A_{i}$ and $N o n D E_{i}$ are as of year $t-1$ (year $t$ respectively). This differentiation does not affect results significantly. In Table 7 (Table D.1), CAR for $[0,+5]$ and $[-5,+5]$ are used as the dependent variable (for $[0,+1]$ and $[-1,+1]$ respectively). This differentiation also leaves results unaffected.

Insert Table 7 about here.

As far as control variables are concerned, the results in Table 7 indicate a significantly negative association between leverage and stock returns, in accordance with evidence on the impact of leverage on market performance generally in the cross-section (e.g. Penman et al., 2007). Furthermore, we get evidence of a negative association between operating performance (EBIT/TA) and market excess returns, implying that the market reacts more 
positively to SB announcements by firms which are weaker from an operational point of view, maybe indicative that 'seeking a buyer' represents the best choice for such firms.

For $D A_{i}$, the results in Table 7 indicate a positive and significant association between discretionary accruals and cumulative abnormal returns around the announcement day for 'seeking buyer' firms. The association appears robust to different $C A R_{i}$ or $D A_{i}$ estimation choices. It implies that the market reacts more positively to SB announcements by firms that engage in upwards EM, a finding that is in accordance with evidence on the impact of DA on market performance in the cross section (e.g. Guay et al., 1996, Subramanyam, 1996).

Given that the 'average' SB firm is found to engage in downwards EM by implementing 'big bath' practices on the announcement year, the results of this section imply that for this firm the market reaction is less favourable. In other words, to the extent that out of the SB firms, those not engaging in downwards EM by implementing big bath practices, are the firms with fewer operating problems at the root of their motivation to issue such an announcement, then evidence is in favour of the market compensating mostly firms which are not subject to very strong operating deficiencies.

\subsection{Earnings management and the acquisition outcome for 'seeking buyer' firms}

We further investigate whether U.S. non-financial listed firms that have issued a 'seeking buyer' announcement between 1990 and 2009 were subsequently acquired. Data on subsequent acquisitions were collected from Thomson One's M\&A database. We define an acquisition as a completed deal, for which the post-event share of the acquirer on the company exceeds $50 \%$.

Insert Table 8 and Figure 3 about here.

Out of the 248 SB firms in our sample, 133 were acquired after the announcement day. For these 133 firms, Figure 3 presents a histogram of the number of years between a SB announcement and a subsequent acquisition. The majority of subsequent acquisitions take 
place within a period of six years from the 'seeking buyer' announcement. There are deals that occur even ten or more years from the announcement date, which are intuitively impossible to relate to the actual announcement. To be conservative, we only consider deals that take place $[0,2]$ years into the future as relevant for the announcement (the first three bars of the histogram in Figure 3).

Table 8 reports information on mean, median, minimum, maximum, and standard deviation of deal size and percentage acquired for the 69 SB firms that were acquired within a period of two years. The average percentage acquired approaches $100 \%$, so the 69 deals in question refer to full stake acquisitions. Mean and median deal sizes (283.56 vs. $46 \$$ million) vary significantly, indicating high standard deviation in the size of the firms acquired.

Furthermore, for these 69 deals, Figures 4 and 5 report information on the number of acquisitions per year on the 2-digit SIC code of the acquirer respectively. When comparing Figure 4 with Figure 1, which reported the number of SB announcements per year, it is readily observed that SB patterns overlap with acquisition patterns, as the greatest number of acquisitions occurs in years 1998 (6 acquisitions) and 2009 (9 acquisitions). Years of significant acquisition activity for SB firms are also 2007 (6 deals), 2001 (5 deals), and the period 1992-1996, with a minimum of 3 deals per year during this time.

Figure 5 indicates that the overwhelming majority of the acquiring firms do not belong to the same sectors as the SB firms: 19 firms belong to SIC code 67, indicating holding and investment firms. There are also 6 acquirers from Business Services (SIC 73), 7 from Chemicals and Allied Products (SIC 28), and 6 from Oil and Gas Extraction (SIC 13). The existence of so many acquirers coming from the financial sector is interpreted as evidence that acquiring firms in essence work in a way as to provide funding to the firms SB, rather than represent same-sector or competitor firms.

Insert Figures 4 and 5 about here. 
To examine the impact of earnings management on the probability that a SB firm can secure an acquisition, we estimate the following logit regression on the sample of all SB firms,

$$
\begin{aligned}
S B A C Q_{i}=\zeta_{0}+ & \zeta_{1} \operatorname{Lev}_{i}+\zeta_{2} C R_{i}+\zeta_{3} \operatorname{Ln}\left(T A_{i}\right)+\zeta_{4} Q_{i}+\zeta_{5} Z_{i}+\zeta_{6}\left(E B I T_{i} / T A_{i}\right)+\zeta_{7} D A_{i} \\
& +\zeta_{8} N_{o n D} E_{i}+v_{i}
\end{aligned}
$$

where the dependent variable, $S B A C Q_{i}$, is a dummy variable that takes the value of one if firm $i$, that has issued a public 'seeking buyer' announcement between 1990 and 2009, is subsequently acquired within a period of two years, and zero otherwise. $C R_{i}$ is the firm's current ratio, and all other variables are as before (see Appendix B for definitions). We wish to examine whether discretionary accruals $D A_{i}$ are important determinants of the probability that a SB firm will be acquired, after controlling for size, leverage, liquidity and distress, growth and unmanaged earnings.

Table 9 reports estimation results, with or without the inclusion of $N o n D E_{i}$ in the right-hand side of the equation. With respect to the behavior of control variables, there is a positive and significant association between firm size and Tobin's Q with the acquisition outcome, implying that larger firms and firms with higher growth potential are more easily acquired. We also report a negative impact between distress (Altman's Z score) and leverage and the acquisition outcome, meaning that acquirers prefer to bid for less distressed and less levered firms. As far as leverage is concerned, this finding is in line with the hypothesis made by Murdoch and Madura (2011, p. 21-22) ${ }^{8}$ and it appears intuitively in line with the previous finding that acquirers will tend to prefer higher growth and less distressed, since leverage and the possibility of distress are not entirely unrelated.

As far as earnings management is concerned, we observe that $D A_{i}$ under the modified Jones and ROA-adjusted specifications positively and significantly relate to the chances of securing an acquisition within two years from the $\mathrm{SB}$ announcement when $N o n D E_{i}$ are included in the model, and this result is also holds when excluding $N o n D E_{i}$ for the Jones and Kothari et al.

\footnotetext{
${ }^{8}$ The finding is however in contrast to their results in Table 7, p. 43.
} 
(2005) specifications. Overall results from Table 9 indicate that there is a positive association between DA and the chance a SB firm will be acquired within a period of two years, after controlling for expected earnings, performance, growth, Altman's Z score and firm size, and the association is robust or incremental to the level of nondiscretionary earnings.

Insert Table 9 here.

Even though our findings indicate that SB firms may be exhibiting some type of 'big bath' behavior with negative DA, on average, on the year of the announcement, the results of Table 9 suggest that the firms eventually acquired are not the ones exhibiting this behavior. The average 'big bath' earnings management behavior of SB firms on year $t$, which we identify in Tables 2-3, is consistent with weak performance in previous years, and implies that reasons one way or another linked to operating performance may be motivating the decision to publicly seek-a-buyer for most SB firms. However, the motivation behind issuing a SB announcement is not performance-related for all such firms: Murdoch and Madura (2011) report that $29 \%$ of the SB announcements are motivated by 'increasing and unlocking value and growth potential for shareholders'. Our results indicate that the firms eventually acquired are the ones that abstain from 'big bath' practices that would result in downwards earnings management, possibly because their motivation for 'seeking a buyer' is not performance related. This condition would imply that prospective bidders may distinguish between the best SB firm candidates and actually prefer firms which are not exceptionally weak from an operating performance point of view. ${ }^{9}$

\section{Conclusions}

Existing research has found consistent evidence of positive earnings management for acquiring firms in mergers and acquisitions. However, in the case of target firms evidence has

\footnotetext{
${ }^{9}$ Results from Tables 7 and 9 are robust to including regressors accounting for institutional and blockholder ownership, despite a reduction in the number of observations upon their inclusion.
} 
been quite context-specific, depending, for example, on whether the acquisition is hostile or not, or on whether a deal is achieved via an auction or via negotiation. This could be possibly attributed to the fact that target firms cannot often anticipate an acquisition proposal, and so they lack both the motive and the time necessary to manage their earnings in order to facilitate or impede the deal.

In this paper, we investigate accruals-based earnings management by firms that openly and actively seek a buyer. We view that these firms, that engage in this rather unusual and largely neglected by previous research corporate event, represent a natural sample of firms that have both time and motive to engage in such actions, as they no longer represent a passive party in an eventual takeover deal. Firms publicly issuing a seeking buyer announcement have been identified to do so for a number of reasons very different from one another, including leverage, undervaluation, growth, strategy-related or distress. We expect that these firms could have two possible motives with respect to earnings management: on one hand, 'window dress' in order to attract a buyer, and on the other hand, manage earnings downwards to facilitate completing a deal from a transaction point of view.

Using all U.S. non-financial listed firms that have publicly announced an intention to be acquired between 1990 and 2009, we first establish that these firms tend to be more levered than matching firms of equivalent size from the same industry, exhibit lower liquidity and growth, and also tend to be slightly worse performers. Importantly, we find that that 'seeking buyer' firms engage in downwards EM for up to two years prior to the event and also in the event year, even after adjusting accruals for performance. This result is robust as far as the announcement year is concerned, even after explicitly controlling for performance, growth and financial distress in the measurement of accruals. This finding seems to suggest that some SB firms exhibit some type of 'big bath' behavior in the year of the 'seeking buyer' announcement. This behavior would allow the firm to make a brand new start, cleansing financial statements before actively seeking a buyer, given that taking a big bath may represent an equilibrium reporting strategy for sufficiently bad news. 
We also provide evidence that the discretionary accruals at the year of the SB announcement, or the year before that, negatively affect the possibility of a firm issuing such an announcement, even after implementing controls for financial distress and firm growth. Smaller, less profitable and more financially distressed firms, as well as firms with a smaller amount of blockholders in their stock ownership structure are found to be more prone to this observed EM behavior among SB firms.

Discretionary accruals positively relate to the stock market abnormal performance of 'seeking buyer' firms around the announcement day, providing an indication that market participants reward the SB firms which do not actually engage in any 'big bath' behaviour. To the extent that this big bath choices are indicative of firms seeking an acquisition for performancerelated reasons, this finding suggests negative market pricing for such motives.

At a final stage we find that earnings management actually improves the possibility for a 'seeking buyer' firm to secure an acquisition within a reasonable period after the relevant announcement. Since SB firms are found to perform downwards EM on average and since a significant proportion of SB announcements are motivated by operating performance, our results suggest that the firms eventually acquired are the ones that abstain from 'big bath' practices, possibly because their motivation for 'seeking a buyer' is not performance-related.

Overall, our findings enhance our understanding of a rather unusual corporate announcement that has not been extensively investigated in the literature and provide evidence regarding the motives behind earnings management by target firms that publicly announce an intention to participate in seller-initiated mergers and acquisitions. Apart from identifying earnings management in a unique event setting, we further provide insights into the consequences of earnings management by target firms that act as acquisition initiators, by explicitly highlighting the consequences of such practices to the facilitation of business transformations. 


\section{References}

Altman,E. (1968) 'Financial ratios, discriminant analysis and the prediction of corporate bankruptcy', The Journal of Finance, 23(4), pp. 589-609.

Anilowski, C., Macias, A., and Sanchez, J.-M. (2009) 'Target firm earnings management and the method of sale: Evidence of auctions and negotiations', Purdue University and University of Arkansas, working paper.

Ball, R., and Shivakumar, L. (2006) 'The role of accruals in asymmetrically timely gain and loss recognition', Journal of Accounting Research, 44(2), pp. 207-42.

Bartov, E., Gul, F., and Tsui, J. (2000) 'Discretionary-accruals models and audit qualifications', Journal of Accounting and Economics, 30(3), pp. 421-52.

Ben-Amar, W., and Missonier-Piera, F. (2008) 'Earnings management by friendly takeover targets', International Journal of Managerial Finance, 4(4), pp. 232-43.

Begley, J., Ming, J., and Watts, S. ( 1996) 'Bankruptcy classification errors in the 1980s: An empirical analysis', Review of Accounting Studies, 1(4), pp. 267-84.

Boehmer, E., Musumeci J., and Poulsen, A. (1991) 'Event study methodology under conditions of event induced variance', Journal of Financial Economics, 30(2), pp. $253-72$.

Christensen, T., Paik, G., and Stice, E. (2008) 'Creating a bigger bath using the deferred tax valuation allowance', Journal of Business Finance and Accounting, 35(5) \& (6), pp. $601-625$

Christie, A.A. and Zimmerman, J.L. (1994) 'Efficient and opportunistic choices of accounting procedures: Corporate control contests', The Accounting Review, 69(4), pp. 539-66.

Cohen, D., and Zarowin, P (2010) 'Accrual-based and real earnings management activities around Seasoned Equity Offerings', Journal of Accounting and Economics, 50(1), pp.2-19.

DeAngelo, H., DeAngelo L., and Skinner. D. (1994) 'Accounting choice in troubled companies', Journal of Accounting and Economics, 17(1), pp. 113-43.

DeFond, M., Park, C. (1997) 'Smoothing income in anticipation of future earnings', Journal of Accounting and Economics, 23(2), pp. 115-39.

Dechow, P.M. and Dichev, I. (2002) 'The quality of accruals and earnings: the role of accrual estimation errors', The Accounting Review, 77 (Supplement), pp. 35-59. 
Dechow, P., Hutton, A., Kim, J.H., and Sloan, R. (2012) 'Detecting earnings management: a new approach', Journal of Accounting Research, 50(2), pp. 275-334.

Dechow,. P.M., Sloan, R.G., and Sweeney, A.P. (1995) 'Detecting earnings management', The Accounting Review, 70(2), pp. 193-225.

Easterwood, C.M. (1998), 'Takeovers and incentives for earnings management: An empirical analysis', Journal of Applied Business Research, 14(1), pp. 29-47.

Ecker, F., Francis, J., Olsson, P. and Schipper, K. (2011) 'Peer firm selection for discretionary accruals models', Duke University working paper.

Eddey, P.H., and Taylor, S.L. (1999), 'Directors' recommendations on takeover bids and the management of earnings: Evidence from Australian takeovers', Abacus, 35(1), pp. $29-44$.

Elliott, J., and Hanna, J.D. (1988) 'Repeated accounting write-offs and the information content of earnings', Journal of Accounting Research, 26(Supplement), pp. 135-55.

Elliott, J., and Shaw, W. (1988) 'Write-offs as accounting procedures to manage perceptions', Journal of Accounting Research, 26(Supplement), pp. 91-119.

Erickson, M. and Wang, S. (1999) 'Earnings management by acquiring firms in stock for stock mergers', Journal of Accounting and Economics, 27(2), pp. 149-76.

Francis, J., LaFond,R., Olsson, P., and Schipper, K. (2005) 'The market pricing of accruals quality'. Journal of Accounting and Economics, 39(2), pp. 295-327.

Guay, W. (2006) 'Discussion of the role and accruals in asymmetrically timely gain and loss recognition', Journal of Accounting Research, 44(2), pp. 243-55.

Guay, W., Kothari, S.P., and Watts, R. (1996) 'A market-based evaluation of discretionary accrual models', Journal of Accounting Research, 34 (Supplement), pp. 83-105.

Hasbrouck, J. (1985) 'The characteristics of takeover targets: Q and other measures', Journal of Banking \& Finance, 9(3), pp. 351-63.

Healy, P. (1996) 'Discussion of a market-based evaluation of discretionary accrual models', Journal of Accounting Research, 34 (Supplement), pp. 107-15.

Healy, P., Palepu, K., and Ruback, R. (1997) 'Which takeovers are profitable? Strategic or financial?', Sloan Management Review, 38(4), pp. 45-57.

Healy, P.M. and Wahlen, J. (1999) 'A review of the earnings management literature and its implication for standards setting', Accounting Horizons, 13(4), pp. 365-83. 
Higgins, J., and Peterson, D. (1998) 'The power of one and two sample t-statistics given event-induced variance increases and nonnormal stock returns: a comparative study', Quarterly Journal of Business and Economics, 37(1), pp. 27-49.

Hribar, P., and Collins, D. (2002) 'Errors in estimating accruals: implications for empirical research', Journal of Accounting Research, 40(1), pp. 105-134.

Jones, J. (1991), 'Earnings management during import relief investigations', Journal of Accounting Research, 29(2), pp. 193-228.

Kirschenheiter, M., and Melumad, N. (2002) 'Can "big bath" and earnings smoothing co-exist as equilibrium financial reporting strategies?', Journal of Accounting Research, 40(3), pp. 761-96.

Kothari, S.P., Leone, A.J., and Wasley, C. (2005) 'Performance matched discretionary accrual measures', Journal of Accounting and Economics, 39(1), pp. 163-97.

Lo, K. (2008) 'Earnings management and earnings quality', Journal of Accounting and Economics, 45(2-3), pp. 350-57.

Louis, H. (2004), 'Earnings management and the market performance of acquiring firms', Journal of Financial Economics, 74(1), pp. 121-48.

Loughran, T., and Ritter, J. (2004) 'Why has IPO underpricing changed over time?' Financial Management, 33(3), pp. 5-37.

Marquardt, C., and Zur, E. (2010) 'The role of accounting quality in the M\&A market', ssrn working paper.

McCulloch, B. (1998) 'Relations among components of accruals under earnings management', ssrn working paper.

McNichols. M. (2000) 'Research design issues in earnings management studies', Journal of Accounting and Public Policy, 19(4-5), pp. 313-45.

McNichols, M., and Stubben, S. (2012) 'The role of target firms' accounting information on acquisitions', Rock Center for Corporate Governance at Stanford University Working Paper No. 81.

Murdoch, M., and Madura, J. (2011) 'Should prospective target firms publicly seek buyers', working paper, 2011 Financial Management Association Applied Finance Conference.

Palepu, K. (1986) 'Predicting takeover targets: a methodological and empirical analysis', Journal of Accounting and Economics, 8(1), pp. 3-35. 
Peltier-Rivest, D. (1999) 'The determinants of accounting choices in troubled companies', Quarterly Journal of Business and Economics, 38(4), pp. 28-44.

Penman, S., Richardson, S., and Tuna, I. (2007) 'The book-to-price effect in stock returns: Accounting for leverage', Journal of Accounting Research, 45(2), pp. 427-467.

Perry, S., and Williams, T. (1994) 'Earnings management preceding management buyout offers', Journal of Accounting and Economics, 18(2), pp. 157-79.

Prevost, A., Skousen, C., and Rao, R. (2008) 'Earnings management and the cost of debt' ssrn working paper.

Raman, K., Shivakumar, L., and Tamayo, A. (2009) 'Targets' earnings quality and bidders' takeover decisions', ssrn working paper.

Ronen, J., and Yaari, V. (2008) Earnings Management: Merging Insights in Theory, Practice and Research, New York: Springer Series in Accounting Scholarship/Springer.

Roychowdhury, S. (2006) 'Earnings management through real activities manipulation', Journal of Accounting and Economics, 42(3), pp. 335-70.

Scholes, M., and Williams, J. (1977) 'Estimating betas from nonsynchronous data', Journal of Financial Economics, 5(3), pp. 309-27.

Skaife, H., and Wangerin, D. (2012) 'Target financial reporting quality and M\&A deals that go bust', Contemporary Accounting Research, published online ahead of print.

Subramanyam, K.R. (1996) 'The pricing of discretionary accruals', Journal of Accounting and Economics', 22(1-2), pp. 249-81.

Wu, Y.W. (1997) 'Management buyouts and earnings management', Journal of Accounting, Auditing and Finance, 12(2), pp. 373-89.

Zhao, Y., and Chen, K. (2008a) 'Staggered boards and earnings management', The Accounting Review, 83(5), pp. 1347-81.

Zhao, Y., and Chen, K. (2008b) 'The influence of takeover protection on earnings management', Journal of Business Finance and Accounting, 35(3-4), pp. 347-75.

Zhong, K., Gribbin, D., and Zheng, X. (2007) 'The effect of monitoring by outside blockholders on earnings management', Quarterly Journal of Economics and Business, 46(1), pp. 37-60. 


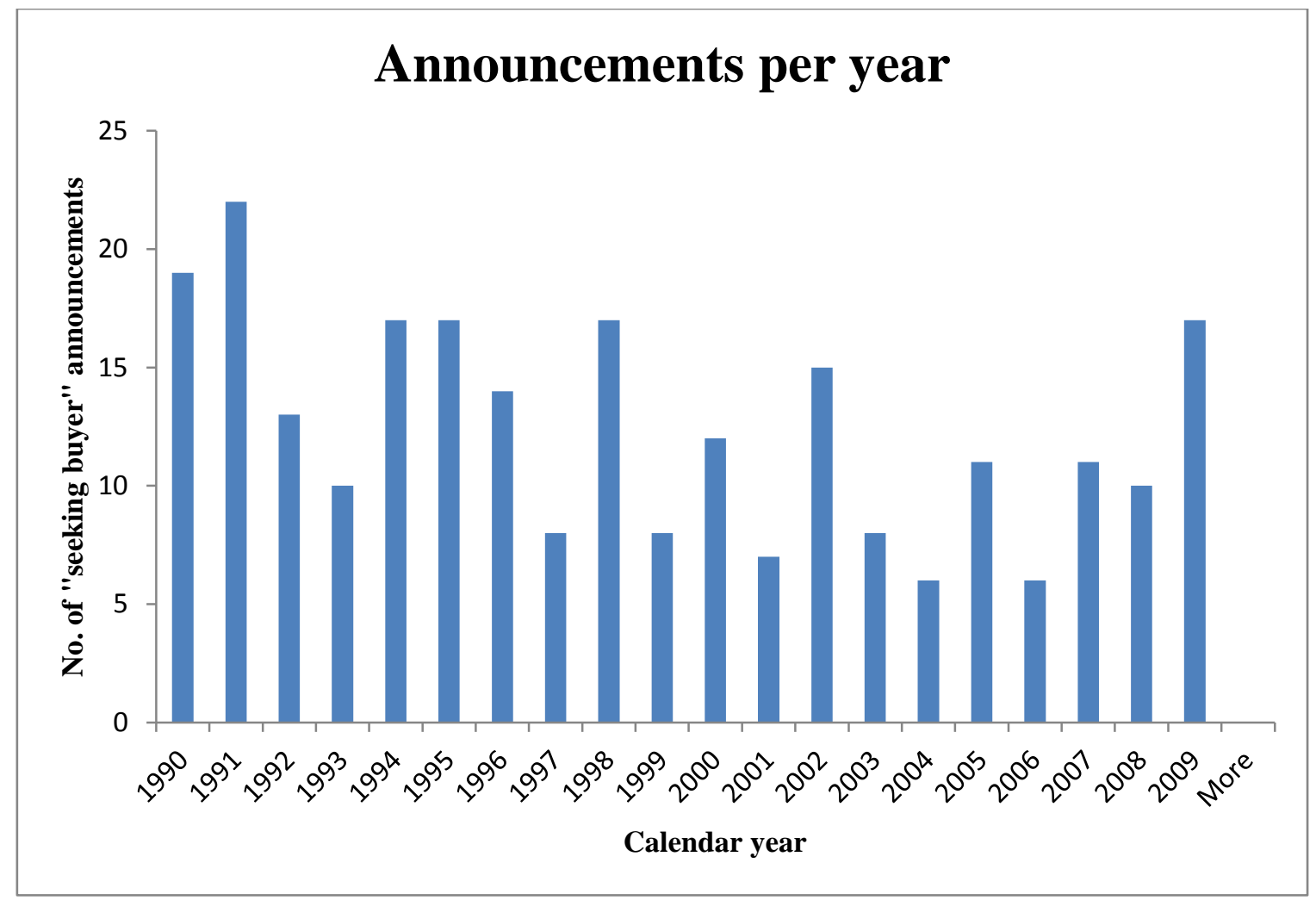

Figure 1: The Figure plots the number of "seeking buyer" announcements by the firms in our sample per calendar year.

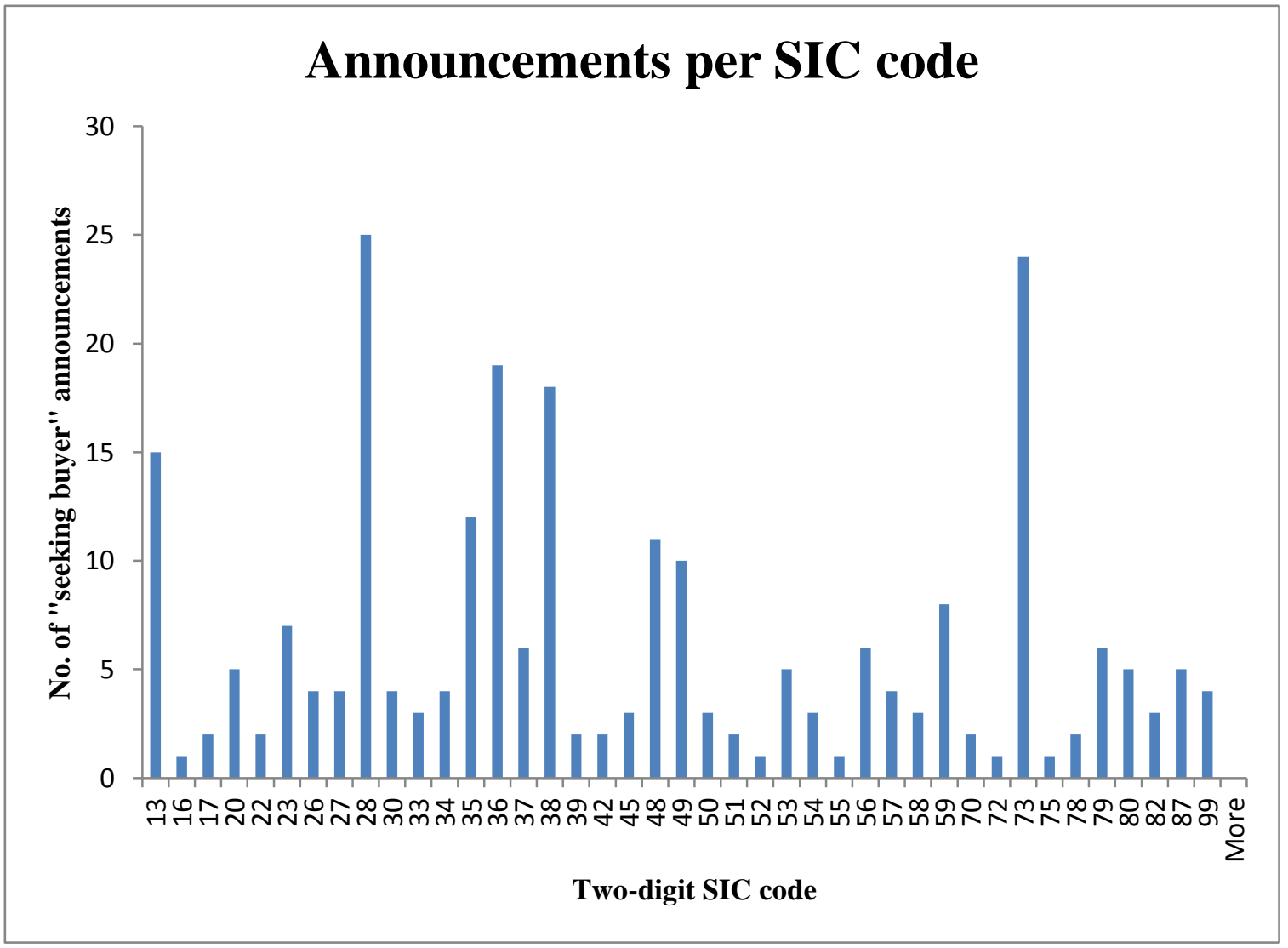

Figure 2: Figure plots the number of "seeking buyer" announcements by the firms in our sample per two-digit SIC code. 


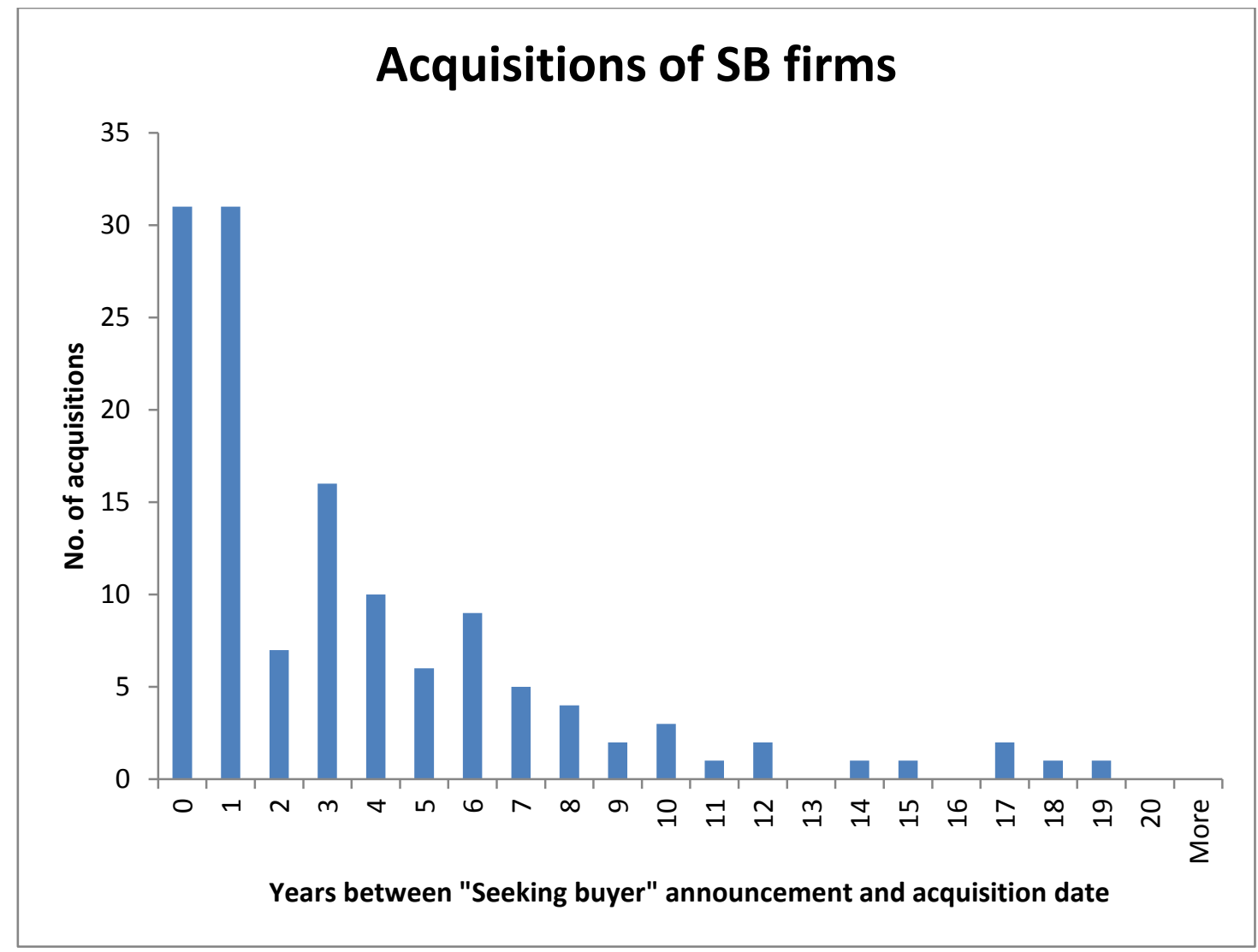

Figure 3: The Figure plots the number of years between a SB announcement and a subsequent acquisition. Out of the 248 SB firms in our sample, 133 were acquired after the announcement.

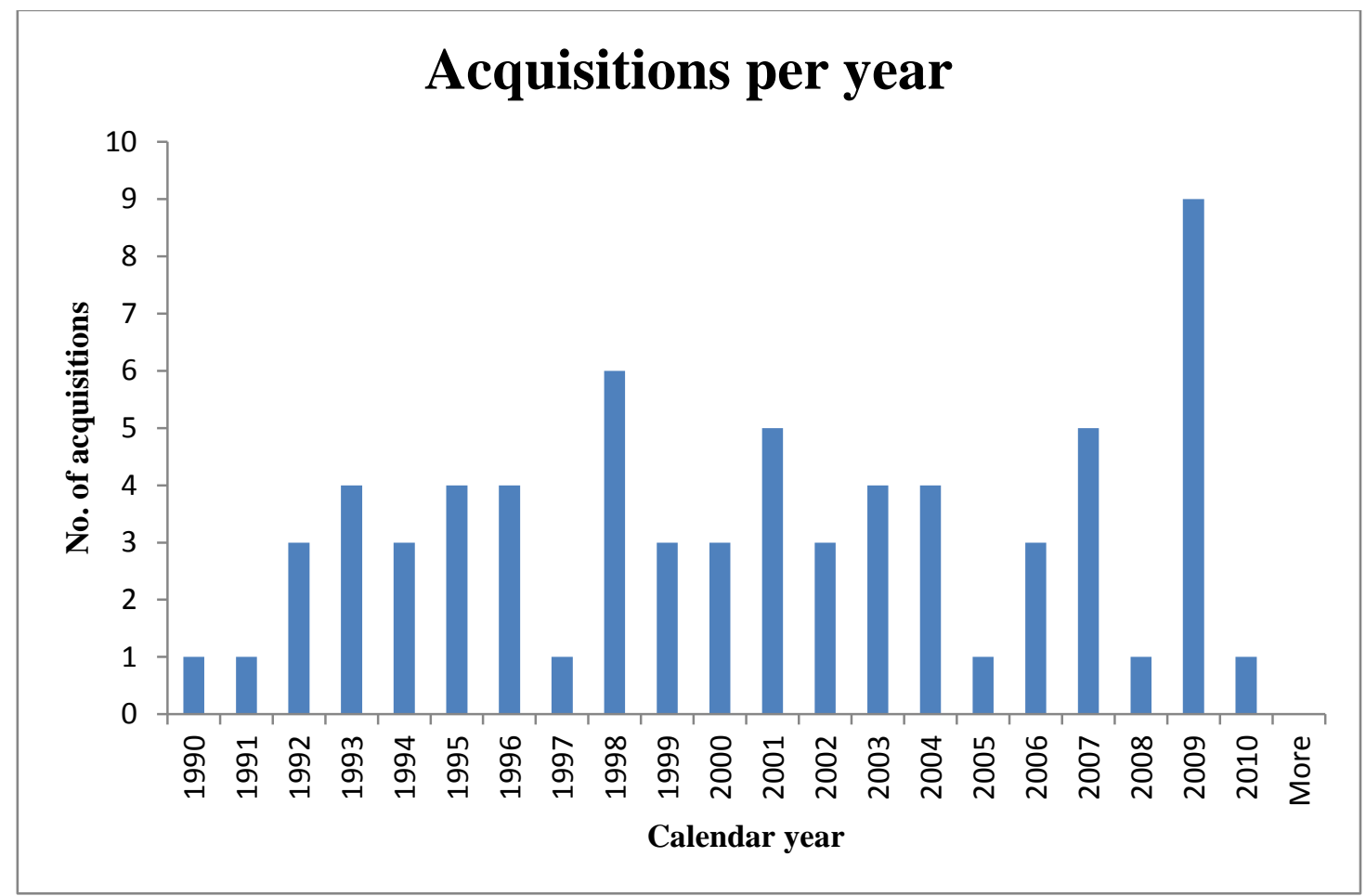

Figure 4: The Figure plots, per calendar year, the number of acquisitions of firms that have publicly announced their intention to be acquired. 


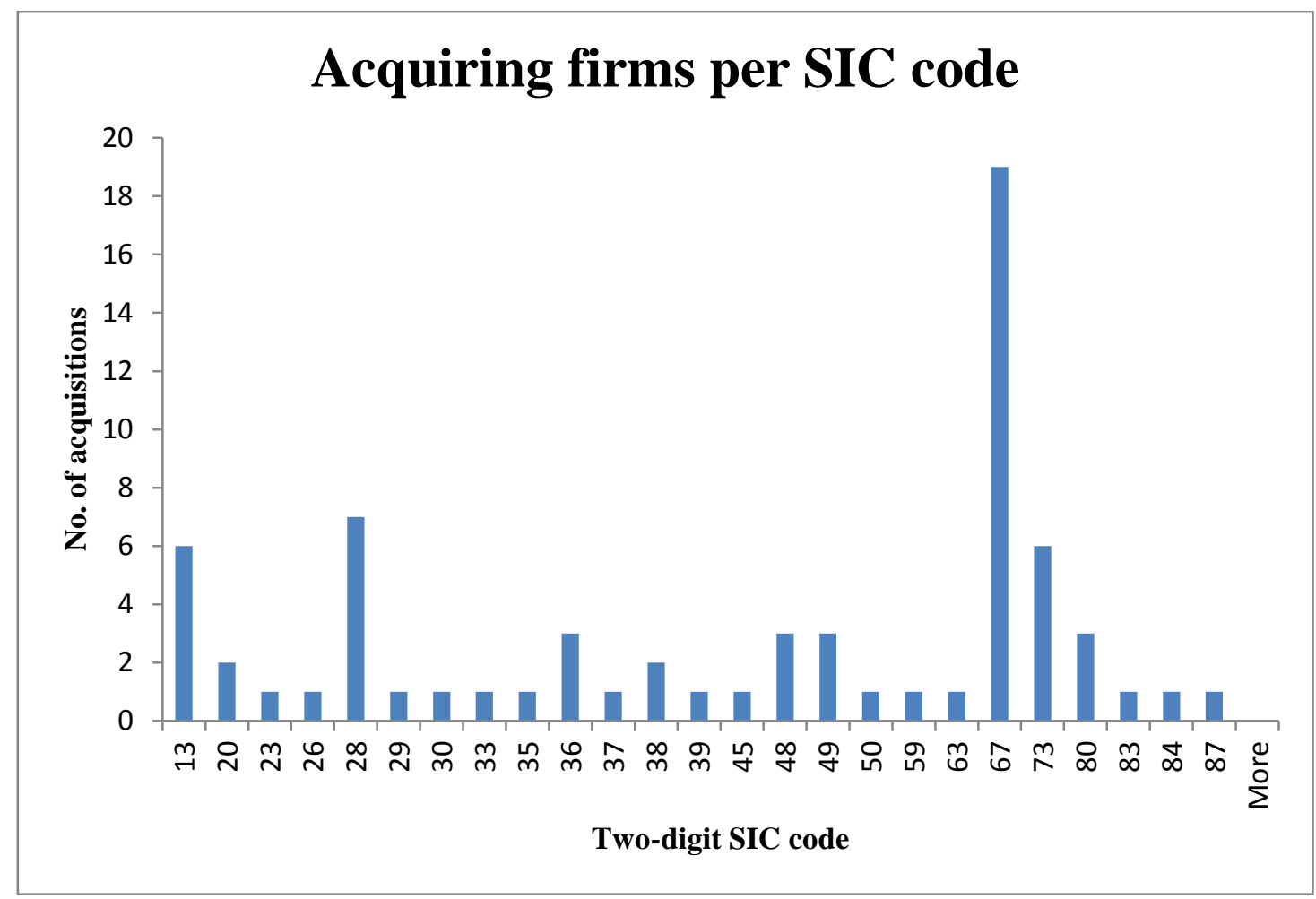

Figure 5: The Figure plots the number of acquiring firms per two-digit SIC code. 
Table 1: The Table reports means and medians for key financial variables of all U.S. non-financial listed firms that have issued a 'seeking buyer' announcement between 1990 and 2009 ('Seeking buyer' firms). All financial variables are defined in Appendix B. Year $t$ refers to the year the 'seeking buyer' announcement is made. For comparison purposes, the corresponding means and medians of two matched samples are also reported in the Table (Matching firms-TA and $M V E$ ). To construct the matching firms' samples, each 'seeking buyer' firm is matched in year $t$ with two firms from the same 4-digit SIC code, based on their market capitalization (the Matching firms- $M V E$ sample), or with two firms from the same 4-digit SIC code based on their total assets (the Matching firms-TA sample). Under Difference, standard t-statistics (for equal means) and Wilcoxon rank sum $\mathrm{z}$-values (for equal medians) are reported. An *,** and *** indicates that the null hypothesis of equal means is rejected at the $10 \%, 5 \%$ and $1 \%$ level of significance respectively. An $\dagger, \dagger \dagger$ and $\dagger \dagger \dagger$ indicates that null hypothesis of equal medians is rejected at the $10 \%, 5 \%$ and $1 \%$ level of significance respectively.

\begin{tabular}{|c|c|c|c|c|c|c|}
\hline \multirow{2}{*}{$\begin{array}{l}\text { Item } \\
\text { ASSETS \& SALES }\end{array}$} & \multicolumn{2}{|c|}{ Year $t-2$} & \multicolumn{2}{|c|}{ Year $t-1$} & \multicolumn{2}{|c|}{ Year $t$} \\
\hline & Mean & Median & Mean & Median & Mean & Median \\
\hline Total Assets (in mil. \$) & & & & & & \\
\hline 'Seeking buyer' firms & $1,062.6$ & 152.38 & $1,222.0$ & 135.75 & $1,479.8$ & 174.79 \\
\hline Matching firms-TA & $1,036.4$ & 127.24 & $1,024.4$ & 125.13 & $1,418.8$ & 174.44 \\
\hline Difference & 0.117 & 0.675 & 0.821 & 1.042 & 0.143 & 0.096 \\
\hline Matching firms- $M V E$ & 966.51 & 101.57 & 971.76 & 95.669 & $1,031.6$ & 96.399 \\
\hline Difference & 0.380 & $2.282 \dagger \dagger$ & 0.932 & $2.312 \dagger \dagger$ & 1.424 & $2.739+\dagger \dagger$ \\
\hline Sales (in mil. \$) & & & & & & \\
\hline 'Seeking buyer' firms & 899.67 & 115.95 & $1,029.0$ & 118.09 & $1,260.3$ & 139.62 \\
\hline Matching firms-TA & 965.46 & 139.17 & 929.66 & 128.76 & 951.79 & 126.88 \\
\hline Difference & -0.316 & -0.381 & 0.471 & 0.138 & 1.247 & 1.292 \\
\hline Matching firms- $M V E$ & 792.37 & 116.16 & 856.69 & 101.41 & 915.64 & 105.68 \\
\hline Difference & 0.562 & 1.053 & 0.789 & 1.365 & 1.310 & $2.297 \dagger \dagger$ \\
\hline
\end{tabular}

PROFITABILITY

ROA

'Seeking buyer' firms

$-0.1010 \quad 0.0355$

$-0.1786$

0.0267

$-0.1272$

0.0286

Matching firms-TA

$-0.1458$

0.0549

$-2.2780$

0.0522

$-0.0816$

0.0567

Difference

0.514

0.680

$-3.648 \dagger \dagger \dagger$

$-0.985$

$-2.104 \uparrow \dagger$

Matching firms- $M V E$

$-0.1373 \quad 0.0548$

$-0.1310$

0.0545

$-0.3795$

0.0452

Difference

$0.566-1.803 \dagger$

$-0.547$

$-2.960 \dagger \dagger \dagger$

0.523

$-1.135$

EBIT/Total Assets

'Seeking buyer' firms

$-0.0989$

0.0329

$-0.1483$

0.0264

$-0.1296$

0.0286

Matching firms-TA

$-0.0473$

0.0590

$-0.0714$

0.0522

$-0.0357$

0.0580

Difference

$-1.206$

$-2.971 \dagger+\dagger$

$-1.686^{*}$

$-3.705 \dagger \dagger \dagger$

$-2.851 * * *$

$-2.339+\dagger$

Matching firms- $M V E$

$-0.0709$

0.0548

$-0.0613$

0.0547

$-0.0758$

0.0455

Difference

$-0.780$

$-2.156 \dagger \dagger$

$-2.443 * *$

$-2.920 \dagger \dagger \dagger$

$-1.515$

$-1.269$

OPER. PERFORMANCE

\section{$\mathrm{CFO} /$ Total Assets}

'Seeking buyer' firms

$\begin{array}{ll}-0.0605 & 0.0385\end{array}$

$-0.1290$

0.0352

$-0.0653$

0.0328

Matching firms-TA

$-0.2971 \quad 0.0476$

$-0.2653$

0.0455

$-4.3757$

0.0538 


\begin{tabular}{|c|c|c|c|c|c|c|}
\hline Difference & 1.180 & 1.185 & 1.029 & 0.724 & 1.089 & 0.612 \\
\hline Matching firms- $M V E$ & -0.4164 & 0.0419 & -0.2482 & 0.0440 & -0.2582 & 0.0421 \\
\hline Difference & $1.681^{*}$ & 0.423 & 0.971 & 0.800 & 1.642 & -0.172 \\
\hline \multicolumn{7}{|l|}{ \&D Expense/Total Assets } \\
\hline 'Seeking buyer' firms & 0.1861 & 0.0717 & 0.2531 & 0.0885 & 0.1640 & 0.0550 \\
\hline Matching firms-TA & 0.2257 & 0.0787 & 0.2082 & 0.0907 & 0.1996 & 0.0729 \\
\hline Difference & -0.624 & 0.823 & 0.518 & 0.369 & -0.678 & 0.856 \\
\hline Matching firms- $M V E$ & 0.3128 & 0.1059 & 0.2143 & 0.1098 & 0.3709 & 0.0930 \\
\hline Difference & -1.279 & 0.236 & 0.529 & 0.598 & -1.434 & 0.761 \\
\hline \multicolumn{7}{|l|}{ P\&E/Total Assets } \\
\hline 'Seeking buyer' firms & 0.2935 & 0.2276 & 0.3008 & 0.2470 & 0.3045 & 0.2391 \\
\hline Matching firms-TA & 0.3000 & 0.2477 & 0.2910 & 0.2283 & 0.2923 & 0.2326 \\
\hline Difference & -0.342 & 0.052 & 0.523 & 1.235 & 0.598 & 1.126 \\
\hline Matching firms- $M V E$ & 0.2934 & 0.2317 & 0.2951 & 0.2269 & 0.3048 & 0.2477 \\
\hline Difference & 0.007 & 0.465 & 0.302 & 1.134 & -0.013 & 0.644 \\
\hline \multicolumn{7}{|l|}{ ap. Exp./Total Assets } \\
\hline 'Seeking buyer' firms & 0.0787 & 0.0535 & 0.0741 & 0.0451 & 0.0648 & 0.0358 \\
\hline Matching firms-TA & 0.0762 & 0.0444 & 0.0657 & 0.0435 & 0.0678 & 0.0442 \\
\hline Difference & 0.207 & $1.745 \dagger$ & 1.340 & 0.883 & -0.403 & $-1.687 \dagger$ \\
\hline Matching firms- $M V E$ & 0.0703 & 0.0453 & 0.0728 & 0.0406 & 0.0628 & 0.0390 \\
\hline Difference & 1.162 & 1.520 & 0.180 & 0.883 & 0.297 & -0.704 \\
\hline
\end{tabular}

LIQUIDITY

Current Ratio

'Seeking buyer' firms

24836

1.8423

2.5746

1.5935

2.9163

1.5251

Matching firms-TA

2.5979

1.8327

2.5066

1.7944

2.6467

1.7515

Difference

$-0.488$

$-0.511$

0.209

$-2.332 \dagger \dagger$

0.508

$-2.435+\dagger$

Matching firms- $M V E$

Difference

3.2639

2.0314

2.7516

1.8411

2.8863

1.8902

$-1.938^{*}$

$-2.043 \dagger \dagger$

$-0.506$

$-2.678+\uparrow \dagger$

0.055

$-3.169+\dagger \dagger$

Quick Ratio

'Seeking buyer' firms

1.9422

1.1374

2.0175

1.1502

2.3175

1.0600

Matching firms-TA

2.0438

1.2620

1.9381

1.2522

2.1118

1.2395

Difference

$-0.440$

$-0.559$

0.251

$-2.029 \dagger \dagger$

0.391

$-2.071+\dagger$

Matching firms- $M V E$

$2.6301 \quad 1.3620$

2.1571

1.2421

2.2620

1.2956

Difference

$-1.714^{*} \quad-1.704 \dagger$

$-0.408$

$-2.168+\dagger$

0.102

$-2.513+\dagger$

LEVERAGE

Long term Debt/Total Assets

'Seeking buyer' firms

0.3105

0.2578

0.2845

0.2652

0.2807

0.2171

Matching firms-TA

0.7003

0.2168

0.6639

0.2269

0.2894

0.2281

Difference

$-0.775$

0.682

$-0.761$

0.682

$-0.324$

$-0.210$ 
Matching firms-MVE

Difference

Total Debt/Total Assets

'Seeking buyer' firms

Matching firms-TA

Difference

Matching firms- $M V E$

Difference

CONTROL VARIABLES
0.2547
$1.980 * *$
0.1908
0.2634
$2.382 \uparrow \dagger$
0.764
0.1984
0.2725
0.1767
$2.050 \uparrow \dagger$
0.238
1.384

$\begin{array}{cccccc}0.3909 & 0.3224 & 0.3910 & 0.3582 & 0.3868 & 0.3484 \\ 0.7748 & 0.2979 & 0.7341 & 0.3067 & 0.3798 & 0.3019 \\ -0.758 & 0.649 & -0.685 & 1.639 & 0.201 & 0.678 \\ & & & & & \\ 0.3423 & 0.2752 & 0.3514 & 0.2869 & 0.3554 & 0.2764 \\ 1.389 & 2.030 \uparrow \dagger & 1.192 & 2.232 \uparrow \dagger & 0.794 & 2.167 \uparrow \dagger\end{array}$

Market-to-Book

'Seeking buyer' firms

2.6305

1.9623

2.4572

1.4931

3.1140

1.6808

Matching firms-TA

Difference

2.5852

1.8759

2.3058

1.7285

0.299

$-1.476$

2.6641

1.6827

0.099

$-0.187$

0.883

$-0.584$

Matching firms- $M V E$

2.4874

1.7479

2.4178

1.6355

2.6949

1.5420

0.302

0.956

0.081

$-0.636$

0.904

0.125

Altman's Z score

'Seeking buyer' firms

2.2880

2.2616

0.6059

1.9743

1.5502

2.0659

Matching firms-TA

3.3293

$-1.398$

$3.8057 \quad 3.0939$

Difference

Matching firms- $M V E$

Difference

2.8601

$-0.781$

$-3.162 \uparrow \uparrow \uparrow$

$-2.594 * * *$

3.4858

3.0639

3.3672

$-3.483+\uparrow \dagger \quad-1.881 *$

$-3.389+1 \dagger$

Sales Growth (SGR)

'Seeking buyer' firms

0.293

3.4128

2.2232

2.9768

2.4085

2.9649

$-2.418 \dagger \dagger$

$-1.783 *$

$-2.181 \dagger \dagger$

$-1.136$

$-2.303+\dagger$

Matching firms-TA

Difference

0.2425

0.0958

0.3076

0.0880

0.0631

0.0151

0.787

0.1002

0.1892

0.0627

0.548

0.1619

0.0595

1.524

$-2.044 * *$

$-3.278+\uparrow+$

Matching firms- $M V E$

0.2254

0.0930

0.2445

0.0847

0.2213

0.0866

Difference

1.019

0.550

0.827

$-0.584$

$-2.358 * *$

$-4.707+\uparrow \dagger$

Tobin's Q

'Seeking buyer' firms

1.9303

1.1391

1.7312

1.0210

1.6603

1.0542

Matching firms-TA

Difference

2.2993

1.2842

2.0599

1.1803

$-0.881$

$-1.745 \dagger$

2.0541

1.1460

$-0.757$

$-1.427$

1.9418

1.1194

$-0.943$

$-1.174$

Matching firms- $M V E$

2.0974

1.2031

$-0.830$

$-1.252$

2.0973

1.1070

$-0.497$

$-0.460$

$-1.071$

$-0.717$

Change in ROA ( $\triangle \mathrm{ROA})$

'Seeking buyer' firms

Matching firms-TA

Difference

\begin{tabular}{cccccc}
-0.0158 & -0.0174 & -0.0237 & -0.0145 & -0.0222 & -0.0053 \\
-0.0170 & -0.0041 & -0.0375 & -0.0078 & 0.0096 & 0.0016 \\
0.036 & $-2.206 \dagger \dagger$ & 0.191 & -1.290 & -1.372 & $-1.739 \dagger$ \\
0.0196 & 0.0020 & 0.0087 & -0.0042 & 0.0232 & -0.0021 \\
-0.929 & $-2.363 \dagger \dagger$ & -0.925 & $-2.447 \dagger \dagger$ & -1.228 & -1.053 \\
\hline
\end{tabular}


Table 2: The Table reports the average, median and standard deviation of discretionary accruals of all listed non-financial U.S. firms that have publicly announced an intention to be acquired. There have been 248 such firms between 1990 and 2009. The models used to distinguish the discretionary and nondiscretionary components of accrual appear in the second column of Panel A, and are explained in the text. In Panel B, we calculate growth-adjusted and distress-adjusted discretionary accruals by making use of matched portfolios based on the change in ROA ( $\triangle$ ROA-matched) and Altman's Z-score (Z scorematched). In both Panels the models are estimated on industry data (two-digit SIC code) with constant terms (intercepts) included in the regressions. N stands for the number of firms with all data available in a given fiscal year and year $t$ is the fiscal year during which the firms publicly announced that an acquirer is sought. An *,** and *** indicates that a t-test for the mean is statistically significant at $10 \%, 5 \%$ and $1 \%$ level of significance respectively. An $\dagger, \dagger \dagger$ and $\dagger \dagger \dagger$ indicates that a z-test for the median (Wilcoxon signed rank test) is statistically significant at $10 \%, 5 \%$ and $1 \%$ level of significance respectively.

Panel A: Discretionary accruals

\begin{tabular}{|c|c|c|c|c|c|c|c|c|c|c|c|c|c|c|c|c|c|}
\hline & & \multicolumn{16}{|c|}{ Year } \\
\hline \multicolumn{2}{|r|}{ Model } & \multicolumn{4}{|c|}{$t-2$} & \multicolumn{4}{|c|}{$t-1$} & \multicolumn{4}{|c|}{$t$} & \multicolumn{4}{|c|}{$t+1$} \\
\hline No. & Name & $\mathrm{N}$ & Mean & St Dev & Median & $\mathrm{N}$ & Mean & St Dev & Median & $\mathrm{N}$ & Mean & St Dev & Median & $\mathrm{N}$ & Mean & St Dev & Median \\
\hline 1 & $\begin{array}{c}\text { Jones } \\
\text { TACFS }\end{array}$ & 161 & $-0.0282 *$ & 0.189 & 0.0061 & 178 & $-0.0313 * *$ & 0.170 & $-0.0075 \dagger$ & 171 & $-0.0367 * * *$ & 0.173 & 0.0049 & 131 & $-0.0177 * * *$ & 0.154 & -0.0018 \\
\hline 2 & $\begin{array}{c}\text { Modified Jones } \\
\text { TACFS }\end{array}$ & 154 & $-0.1656^{* * *}$ & 0.292 & $-0.1287 \dagger+\dagger$ & 146 & $-0.1941 * * *$ & 0.268 & $-0.1392 \dagger \dagger \dagger$ & 137 & $-0.1676^{* * *}$ & 0.169 & $-0.1231 \dagger \dagger \dagger$ & 124 & $-0.1662 * * *$ & 0.185 & $-0.1267 \dagger \dagger \dagger$ \\
\hline 3 & $\begin{array}{c}\text { Ball Shivakumar } \\
\text { TACFS }\end{array}$ & 159 & $-0.0431 * * *$ & 0.176 & $-0.0036 \dagger \dagger$ & 177 & $-0.0318 * * *$ & 0.154 & $-0.0077 \dagger \dagger$ & 171 & $-0.0419 * * *$ & 0.169 & $0.0022 \dagger$ & 129 & -0.0197 & 0.147 & 0.0060 \\
\hline 4 & $\begin{array}{c}\text { Kothari et al. } \\
\text { TACFS-ROA } \\
\text { matched }\end{array}$ & 139 & -0.0168 & 0.157 & -0.0013 & 132 & $-0.0165^{*}$ & 0.111 & -0.0073 & 133 & $-0.0192 * *$ & 0.109 & -0.0002 & 111 & -0.0065 & 0.115 & 0.0005 \\
\hline
\end{tabular}


Panel B: Growth and distress adjusted discretionary accruals

\begin{tabular}{|c|c|c|c|c|c|c|c|c|c|c|c|c|c|c|c|c|c|}
\hline & & \multicolumn{16}{|c|}{ Year } \\
\hline \multicolumn{2}{|r|}{ Model } & \multicolumn{4}{|c|}{$t-2$} & \multicolumn{4}{|c|}{$\mathrm{t}-1$} & \multicolumn{4}{|c|}{$\mathrm{t}$} & \multicolumn{4}{|c|}{$t+1$} \\
\hline No. & Name & $\mathrm{N}$ & Mean & St Dev & Median & $\mathrm{N}$ & Mean & St Dev & Median & $\mathrm{N}$ & Mean & St Dev & Median & $\mathrm{N}$ & Mean & St Dev & Median \\
\hline $1 \mathrm{a}$ & $\begin{array}{c}\text { Jones } \\
\text { TACFS- } \triangle \text { ROA } \\
\text { matched }\end{array}$ & 140 & -0.0251 & 0.182 & 0.0013 & 155 & -0.0117 & 0.153 & -0.0011 & 149 & $-0.0319 * * *$ & 0.137 & -0.0074 & 119 & -0.0127 & 0.125 & -0.0015 \\
\hline $1 b$ & $\begin{array}{c}\text { Jones } \\
\text { TACFS-Z score } \\
\text { matched }\end{array}$ & 113 & -0.0220 & 0.193 & 0.0032 & 113 & -0.0214 & 0.154 & -0.0009 & 97 & $-0.0253 *$ & 0.151 & -0.0001 & 78 & -0.0153 & 0.151 & -0.0056 \\
\hline $2 a$ & $\begin{array}{c}\text { Mod. Jones } \\
\text { TACFS- } \triangle \text { ROA } \\
\text { matched }\end{array}$ & 132 & -0.0233 & 0.194 & -0.0014 & 124 & -0.0123 & 0.136 & -0.0011 & 120 & $-0.0352 * * *$ & 0.120 & $-0.0086 \dagger \dagger \dagger$ & 112 & -0.0089 & 0.118 & -0.0074 \\
\hline $2 b$ & $\begin{array}{c}\text { Mod. Jones } \\
\text { TACFS-Z score } \\
\text { matched }\end{array}$ & 103 & -0.0302 & 0.200 & -0.0017 & 88 & -0.0349 & 0.200 & -0.0099 & 87 & $-0.0348 * *$ & 0.148 & -0.0052 & 78 & -0.0093 & 0.140 & -0.0045 \\
\hline $3 a$ & $\begin{array}{c}\text { Ball Shivakumar } \\
\text { TACFS- } \triangle \text { ROA } \\
\text { matched }\end{array}$ & 140 & -0.0158 & 0.176 & -0.0004 & 153 & -0.0149 & 0.158 & -0.0016 & 152 & $-0.0298 * * *$ & 0.136 & -0.0030 & 117 & -0.0093 & 0.126 & -0.0094 \\
\hline $3 b$ & $\begin{array}{l}\text { Ball Shivakumar } \\
\text { TACFS-Z score } \\
\text { matched }\end{array}$ & 113 & -0.0268 & 0.185 & 0.0040 & 112 & -0.0196 & 0.163 & -0.0007 & 96 & -0.0235 & 0.152 & 0.0027 & 78 & -0.0140 & 0.148 & -0.0030 \\
\hline
\end{tabular}


Table 3: The Table reports means and medians of discretionary accruals by all U.S. non-financial listed firms that have issued a 'seeking buyer' announcement between 1990 and 2009 ('Seeking buyer' firms). These are identical to the ones in Table 2. Year $t$ refers to the year the 'seeking buyer' announcement is made. For comparison purposes, the corresponding means and medians of two matched samples are also reported in the Table (Matching firms-MVE and TA). To construct the matching firms' samples, each 'seeking buyer' firm is matched in year $t$ with two firms from the same 4-digit SIC code based on their market capitalization (the Matching firms-MVE sample), or with two firms from the same 4-digit SIC code based on their total assets (the Matching firms-TA sample). An *,** and *** indicates that the null hypothesis of a zero mean is rejected at the $10 \%, 5 \%$ and $1 \%$ level of significance respectively. An $\dagger, \dagger \dagger$ and $\dagger \dagger \dagger$ indicates that null hypothesis of a zero median is rejected at the $10 \%, 5 \%$ and $1 \%$ level of significance respectively. Under Difference statistic, standard t-statistics (for equal means) and Wilcoxon rank sum z-values (for equal medians) are reported. An \#, \#\# and \#\#\# indicates that the null hypothesis of equal means is rejected at the $10 \%, 5 \%$ and $1 \%$ level of significance respectively. An $\S$, $\S$ and $\S \S \S$ indicates that null hypothesis of equal medians is rejected at the $10 \%, 5 \%$ and $1 \%$ level of significance respectively.

Panel A: Discretionary accruals

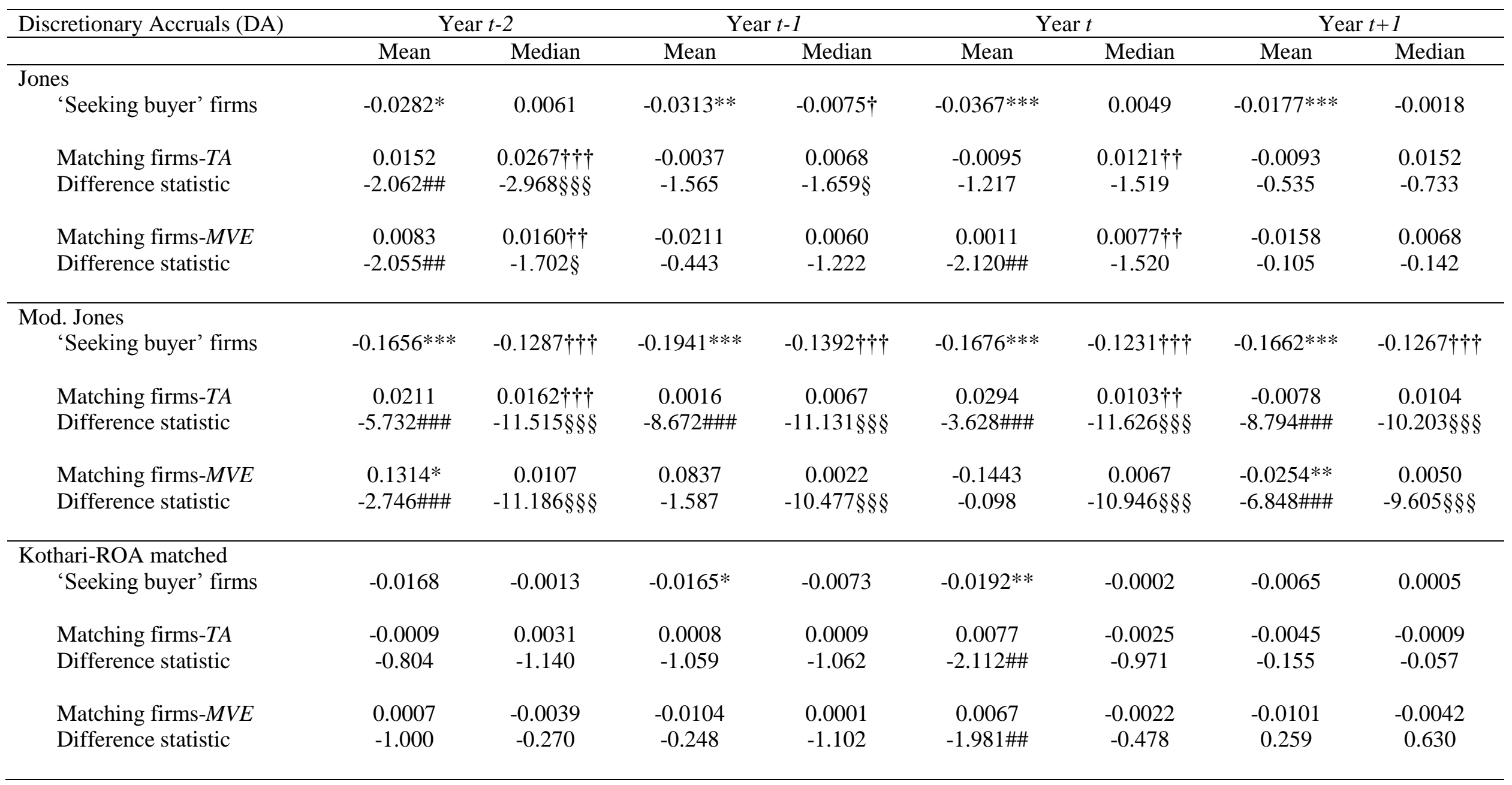


Panel B: Growth and distress adjusted discretionary accruals

\begin{tabular}{|c|c|c|c|c|c|c|c|c|}
\hline \multirow{2}{*}{$\begin{array}{l}\text { Discretionary Accruals (DA) } \\
\text { Adjusted for Growth and Distress }\end{array}$} & \multicolumn{2}{|c|}{ Year $t-2$} & \multicolumn{2}{|c|}{ Year $t-1$} & \multicolumn{2}{|c|}{ Year $t$} & \multicolumn{2}{|c|}{ Year $t+1$} \\
\hline & Mean & Median & Mean & Median & Mean & Median & Mean & Median \\
\hline \multicolumn{9}{|l|}{ Jones $\Delta$ ROA-matched } \\
\hline 'Seeking buyer' firms & -0.0251 & 0.0013 & -0.0117 & -0.0011 & $-0.0319 * * *$ & -0.0074 & -0.0127 & -0.0015 \\
\hline Matching firms-TA & 0.0155 & $0.0114 \dagger$ & 0.0062 & -0.0015 & 0.0067 & -0.0006 & $0.0113^{*}$ & 0.0005 \\
\hline Difference statistic & $-2.369 \# \#$ & -1.498 & -0.337 & -0.457 & $-1.679 \#$ & -1.304 & -0.111 & -0.194 \\
\hline Matching firms- $M V E$ & 0.0074 & 0.0006 & $-0.0280^{*}$ & -0.0018 & -0.0101 & -0.0020 & -0.0098 & -0.0059 \\
\hline Difference statistic & $-1.873 \#$ & -0.605 & 0.662 & 0.181 & -1.218 & -0.954 & -0.197 & -0.008 \\
\hline \multicolumn{9}{|l|}{ Jones Altman Z score-matched } \\
\hline 'Seeking buyer' firms & -0.0220 & 0.0032 & -0.0214 & -0.0009 & $-0.0253 *$ & -0.0001 & -0.0153 & -0.0056 \\
\hline Matching firms-TA & 0.011 & $0.0092 \dagger$ & -0.0152 & -0.0081 & -0.0232 & 0.0076 & -0.0066 & 0.0018 \\
\hline Difference statistic & -1.427 & -1.031 & -0.298 & -0.134 & -0.059 & -0.698 & -0.482 & -0.559 \\
\hline Matching firms- $M V E$ & 0.0036 & 0.0012 & $-0.0306^{*}$ & $-0.0049+\dagger$ & -0.0061 & -0.0016 & -0.0166 & -0.0016 \\
\hline Difference statistic & -1.272 & -0.079 & 0.305 & 0.211 & -0.830 & -0.186 & 0.055 & -0.127 \\
\hline \multicolumn{9}{|l|}{ Mod. Jones $\triangle \mathrm{ROA}$-matched } \\
\hline 'Seeking buyer' firms & -0.0233 & -0.0014 & -0.0123 & -0.0011 & $-0.0352 * * *$ & $-0.0086+1+$ & -0.0089 & -0.0074 \\
\hline Matching firms-TA & 0.0089 & 0.0017 & -0.0009 & 0.0001 & -0.0032 & -0.0000 & $-0.0123 *$ & -0.0032 \\
\hline Difference statistic & $-1.727 \#$ & -1.243 & -0.631 & -0.209 & $-2.099 \# \#$ & $-2.393 \S \S$ & 0.258 & -0.192 \\
\hline Matching firms- $M V E$ & 0.0296 & 0.0028 & -0.0250 & -0.0035 & -0.0079 & -0.0022 & $-0.0143^{*}$ & -0.0066 \\
\hline Difference statistic & -1.372 & -0.880 & 0.450 & 0.531 & $-1.719 \#$ & $-1.805 \S$ & 0.362 & 0.034 \\
\hline \multicolumn{9}{|l|}{ Mod. Jones Altman Z score-matched } \\
\hline 'Seeking buyer' firms & -0.0302 & -0.0017 & -0.0349 & -0.0099 & $-0.0348 * *$ & -0.0052 & -0.0093 & -0.0045 \\
\hline Matching firms-TA & 0.0160 & 0.0073 & -0.0099 & -0.0037 & 0.0075 & 0.0065 & -0.0094 & -0.0018 \\
\hline Difference statistic & $-1.912 \#$ & -1.416 & -1.040 & -0.744 & $-2.318 \# \#$ & $-1.782 \S$ & 0.0065 & 0.075 \\
\hline Matching firms- $M V E$ & 0.095 & -0.0033 & -0.0249 & -0.0024 & -0.0063 & -0.0005 & $-0.0272 * *$ & $-0.0064 \uparrow$ \\
\hline Difference statistic & -1.102 & -0.359 & -0.272 & -0.534 & $-1.702 \#$ & -0.533 & 0.815 & 0.667 \\
\hline
\end{tabular}


Table 4: The Table reports the estimation results of the pooled regression

$D A_{i}=\beta_{0}+\beta_{1} L_{e v}+\beta_{2} L n\left(T A_{i}\right)+\beta_{3} S G R_{i}+\beta_{4} Z_{i}+\beta_{5}\left(E B I T_{i} / T A_{i}\right)+\beta_{6} I N S T_{i}+\beta_{7} B L O C K_{i}+\beta_{8} B I G 4_{i}+\beta_{9} N_{o n D E}+u_{i}$ The regression is estimated on the sample of all U.S. non-financial listed firms that have issued a 'seeking buyer' (SB) announcement between 1990 and 2009. The dependent variables $D A_{i}$ are the discretionary accruals of firm $i$ in year $t$ (the year of the 'seeking buyer' announcement). $L e v_{i}$ is the leverage of firm $i$, calculated as total debt over total assets, while $\operatorname{Ln}\left(T A_{i}\right)$ is the natural logarithm of firm's $i$ total assets. $S G R_{i}$ is the annual sales growth of firm $i$, calculated as the percentage change in sales between year $t-1$ and year $t . Z_{i}$ is the firm's Altman Z-score, and $\left(E B I T_{i} / T A_{i}\right)$ is the firm's earnings before interest and tax, over total assets. $N o n D E_{i}$ stands for the firm's nondiscretionary earnings. INST $i$ and $B L O C K_{i}$ stand for firm $i$ percentage of stock owned by institutional investors and blockholders respectively, in the total amount of the outstanding common stock the quarter immediately before the 'seeking buyer' (SB) announcement. $B I G 4_{i}$ is a dummy variable that takes the value of one if the auditor of firm $i$ in year $t$ is a 'big 4' firm, and zero otherwise. All independent variables are as of year $t$ (the year of the 'seeking buyer' announcement), and t-statistics are reported in parentheses. An *, ** and $* * *$ indicates statistical significance at the $10 \%, 5 \%$ and $1 \%$ level respectively.

\begin{tabular}{|c|c|c|c|c|}
\hline Independent Variable & $\begin{array}{c}(1) \\
\text { Jones } \\
\text { DA }\end{array}$ & $\begin{array}{c}(2) \\
\text { Mod. Jones } \\
\text { DA }\end{array}$ & $\begin{array}{c}\text { (3) } \\
\text { Kothari ROA- } \\
\text { matched DA }\end{array}$ & $\begin{array}{c}(4) \\
\text { Ball-Shivakumar } \\
\text { DA }\end{array}$ \\
\hline Intercept & $\begin{array}{c}-0.117 * * \\
(-2.04)\end{array}$ & $\begin{array}{c}-0.197 * * \\
(-2.54)\end{array}$ & $\begin{array}{c}-0.157 * * * \\
(-3.50)\end{array}$ & $\begin{array}{c}-0.094 * \\
(-1.85)\end{array}$ \\
\hline Lev $_{i}$ & $\begin{array}{l}0.053 \\
(0.91)\end{array}$ & $\begin{array}{l}-0.004 \\
(-0.06)\end{array}$ & $\begin{array}{l}0.060 \\
(1.10)\end{array}$ & $\begin{array}{l}0.048 \\
(0.89)\end{array}$ \\
\hline $\operatorname{Ln}\left(T A_{i}\right)$ & $\begin{array}{l}0.013 \\
(1.11)\end{array}$ & $\begin{array}{l}0.016 \\
(1.11)\end{array}$ & $\begin{array}{l}0.019^{*} \\
(1.90)\end{array}$ & $\begin{array}{l}0.004 \\
(0.35)\end{array}$ \\
\hline$S G R_{i}$ & $\begin{array}{l}-0.006 \\
(-0.59)\end{array}$ & $\begin{array}{l}-0.001 \\
(-0.49)\end{array}$ & $\begin{array}{l}0.003 \\
(1.47)\end{array}$ & $\begin{array}{l}-0.004 \\
(-0.66)\end{array}$ \\
\hline$Z_{i}$ & $\begin{array}{c}0.010^{* *} \\
(2.52)\end{array}$ & $\begin{array}{c}0.012 * * \\
(2.55)\end{array}$ & $\begin{array}{c}0.015 * * * \\
(4.31)\end{array}$ & $\begin{array}{c}0.009 * * \\
(2.58)\end{array}$ \\
\hline$\left(E B I T_{i} / T A_{i}\right)$ & $\begin{array}{c}0.351^{* *} \\
(2.60)\end{array}$ & $\begin{array}{c}0.463^{* *} \\
(2.47)\end{array}$ & & $\begin{array}{c}0.327 * * * \\
(3.20)\end{array}$ \\
\hline$I N S T_{i}$ & $\begin{array}{l}0.002 \\
(0.02)\end{array}$ & $\begin{array}{l}0.019 \\
(0.19)\end{array}$ & $\begin{array}{l}-0.099 \\
(-1.33)\end{array}$ & $\begin{array}{l}0.061 \\
(0.72)\end{array}$ \\
\hline$B L O C K_{i}$ & $\begin{array}{l}0.037 \\
(0.39)\end{array}$ & $\begin{array}{l}0.005 \\
(0.05)\end{array}$ & $\begin{array}{c}0.157^{*} \\
(1.83)\end{array}$ & $\begin{array}{l}-0.029 \\
(-0.33)\end{array}$ \\
\hline$B I G 4_{i}$ & $\begin{array}{l}-0.046 \\
(-1.18)\end{array}$ & $\begin{array}{l}-0.022 \\
(-0.48)\end{array}$ & $\begin{array}{l}0.012 \\
(0.38)\end{array}$ & $\begin{array}{l}-0.028 \\
(-0.75)\end{array}$ \\
\hline $\operatorname{NonDE}_{i}$ & $\begin{array}{c}-0.352 * * \\
(-2.14)\end{array}$ & $\begin{array}{c}-0.670 * * * \\
(-3.74)\end{array}$ & $\begin{array}{c}-0.304 * * \\
(-2.49)\end{array}$ & $\begin{array}{c}-0.258 * * \\
(-2.54)\end{array}$ \\
\hline$R^{2}$ & 0.509 & 0.615 & 0.378 & 0.534 \\
\hline$F$ & $6.02 * * *$ & $9.29 * * *$ & $3.01^{* * *}$ & $7.46^{* * *}$ \\
\hline No. Obs. & 89 & 80 & 79 & 89 \\
\hline
\end{tabular}


Table 5: The Table reports in Panel A the estimation results of the pooled logit regression

$$
\begin{gathered}
S B_{i}=\gamma_{0}+\gamma_{1}(W C / T A)_{i}+\gamma_{2}\left(R E_{i} / T A_{i}\right)+\gamma_{3}\left(E B I T_{i} / T A_{i}\right)+\gamma_{4}\left(M V E_{i} / T L_{i}\right)+\gamma_{5}\left(S A L E S_{i} / T A_{i}\right)+\gamma_{6} \Delta R O A_{i}+\gamma_{7} \operatorname{Ln}\left(T A_{i}\right) \\
+\gamma_{8} D A_{i}+\gamma_{9} N o n D E_{i}+u_{i}
\end{gathered}
$$

In Panel $\mathrm{B}, N o n D E_{i}$ is excluded from the model. The regression is estimated on the union of two samples, one consisting of all U.S. non-financial listed firms that have issued a 'seeking buyer' (SB) announcement between 1990 and 2009, and a matched sample based on industry and total assets. To construct the matching firms' sample, each SB firm is matched in the year of the SB announcement with two firms from the same 4-digit SIC code based on their total assets. The dependent variable $S B_{i}$ is a dummy variable that takes the value of one if firm $i$ has issued a public 'seeking buyer' announcement between 1990 and 2009 , and zero otherwise. $(W C / T A)_{i}$ equals working capital total assets $(T A),\left(R E_{i} / T A_{i}\right)$ is the ratio of retained earnings/TA, $\left(E B I T_{i} /\right.$ $\left.T A_{i}\right)$, and $\left(S A L E S_{i} / T A_{i}\right)$ equals earnings before interest and tax, and sales, respectively, over TA, $\left(M V E_{i} / T A_{i}\right)$ equals MVE over total liabilities, while $\operatorname{Ln}\left(T A_{i}\right)$ is the natural logarithm of firm's $i$ total assets. $Q_{i}$ is the firm's Tobin $\mathrm{Q}$ and $D A_{i}$ and $N o n D E_{i}$ stand for the firm's discretionary accruals and nondiscretionary earnings respectively. All independent variables except for $D A_{i}$ and $N o n D E_{i}$ are as of year $t$ (the year of the 'seeking buyer' announcement), and t-statistics are reported in parentheses. The Table reports results for discretionary accruals calculated from the Modified Jones model (specifications (1) and (3)) and the Kothari ROA-matched model (specifications (2) and (4)), as of year $t-1$ (specifications (1) and (2)) and as of year $t$ (specifications (3) and (4)). An *,** and *** indicates statistical significance at the 10\%, 5\% and $1 \%$ level respectively.

\begin{tabular}{|c|c|c|c|c|}
\hline Specification & $\begin{array}{c}(1) \\
\text { Mod. Jones DA } \\
\text { and NonDE of } \\
\text { year } t-1 \text { in } \\
\text { regressors }\end{array}$ & $\begin{array}{c}(2) \\
\text { Kothari ROA- } \\
\text { matched DA and } \\
\text { NonDE of year } t-1 \\
\text { in regressors }\end{array}$ & $\begin{array}{c}(3) \\
\text { Mod. Jones DA } \\
\text { and NonDE of } \\
\text { year } t \text { in } \\
\text { regressors }\end{array}$ & $\begin{array}{c}(4) \\
\text { Kothari ROA- } \\
\text { matched DA and } \\
\text { NonDE of year } t \text { in } \\
\text { regressors }\end{array}$ \\
\hline Intercept & $\begin{array}{c}-1.539 * * * \\
(-2.60)\end{array}$ & $\begin{array}{l}-0.012 \\
(-0.02)\end{array}$ & $\begin{array}{c}-1.483^{* *} \\
(-2.38)\end{array}$ & $\begin{array}{l}-0.099 \\
(-0.19)\end{array}$ \\
\hline$\left(W C_{i} / T A_{i}\right)$ & $\begin{array}{l}0.483 \\
(0.79)\end{array}$ & $\begin{array}{l}-0.649 \\
(-1.09)\end{array}$ & $\begin{array}{l}0.830 \\
(1.33)\end{array}$ & $\begin{array}{l}-1.040^{*} \\
(-1.84)\end{array}$ \\
\hline$\left(R E_{i} / T A_{i}\right)$ & $\begin{array}{l}-0.133 \\
(-1.21)\end{array}$ & $\begin{array}{c}-0.235^{* *} \\
(-2.47)\end{array}$ & $\begin{array}{l}0.242 \\
(1.40)\end{array}$ & $\begin{array}{l}-0.086 \\
(-1.57)\end{array}$ \\
\hline$\left(E B I T_{i} / T A_{i}\right)$ & $\begin{array}{l}0.017 \\
(0.02)\end{array}$ & & $\begin{array}{l}-2.492 \\
(-1.01)\end{array}$ & \\
\hline$\left(M V E_{i} / T L_{i}\right)$ & $\begin{array}{l}-0.017 \\
(-1.42)\end{array}$ & $\begin{array}{l}-0.019 \\
(-1.10)\end{array}$ & $\begin{array}{l}-0.006 \\
(-0.69)\end{array}$ & $\begin{array}{l}-0.003 \\
(-0.28)\end{array}$ \\
\hline$\left(S A L E S_{i} / T A_{i}\right)$ & $\begin{array}{l}-0.292 \\
(-1.32)\end{array}$ & $\begin{array}{l}-0.349 \\
(-1.49)\end{array}$ & $\begin{array}{c}-0.424 * * \\
(-1.98)\end{array}$ & $\begin{array}{l}-0.235 \\
(-1.13)\end{array}$ \\
\hline$\triangle R O A_{i}$ & $\begin{array}{c}-2.747 * * \\
(-2.30)\end{array}$ & $\begin{array}{l}0.181 \\
(0.13)\end{array}$ & $\begin{array}{l}1.322 \\
(1.47)\end{array}$ & $\begin{array}{l}-0.581 \\
(-0.33)\end{array}$ \\
\hline $\operatorname{Ln}\left(T A_{i}\right)$ & $\begin{array}{l}0.075 \\
(0.88)\end{array}$ & $\begin{array}{l}-0.096 \\
(-1.29)\end{array}$ & $\begin{array}{l}0.062 \\
(0.71)\end{array}$ & $\begin{array}{l}-0.074 \\
(-0.99)\end{array}$ \\
\hline$D A_{i}($ Mod. Jones of year $t-1$ or $t)$ & $\begin{array}{c}-7.181 * * * \\
(-4.50)\end{array}$ & & $\begin{array}{c}-10.040 * * * \\
(-3.83)\end{array}$ & \\
\hline$N o n D E_{i}$ (Mod. Jones of year $t-1$ or $t$ ) & $\begin{array}{l}1.590 \\
(1.20)\end{array}$ & & $\begin{array}{l}4.310^{*} \\
(1.65)\end{array}$ & \\
\hline$D A_{i}($ Kothari-ROA of year $t-1$ or $t)$ & & $\begin{array}{l}1.891 \\
(0.99)\end{array}$ & & $\begin{array}{l}0.828 \\
(0.36)\end{array}$ \\
\hline$N o n D E_{i}$ (Kothari-ROA of year $t-1$ or $\left.t\right)$ & & $\begin{array}{c}6.225^{* *} \\
(2.48)\end{array}$ & & $\begin{array}{c}5.309 * * * \\
(2.88)\end{array}$ \\
\hline Pseudo $R^{2}$ & 0.208 & 0.122 & 0.312 & 0.107 \\
\hline Wald $\chi^{2}$ & $28.490 * * *$ & 10.510 & $33.220 * * *$ & $15.800^{* *}$ \\
\hline No. Obs. & 359 & 322 & 344 & 330 \\
\hline
\end{tabular}

Panel A: Nondiscretionary earnings $N o n D E_{i}$ are included in regressors 
Panel B: Nondiscretionary earnings $N o n D E_{i}$ are excluded from regressors

\begin{tabular}{|c|c|c|c|c|}
\hline Specification & $\begin{array}{c}(1) \\
\text { Mod. Jones } \\
\text { DA of year } t-1 \\
\text { in regressors }\end{array}$ & $\begin{array}{c}(2) \\
\text { Kothari ROA- } \\
\text { matched DA of year } \\
t-1 \text { in regressors }\end{array}$ & $\begin{array}{c}\text { (3) } \\
\text { Mod. Jones DA } \\
\text { of year } t \text { in } \\
\text { regressors }\end{array}$ & $\begin{array}{c}(4) \\
\text { Kothari ROA- } \\
\text { matched DA of year } \\
t \text { in regressors }\end{array}$ \\
\hline Intercept & $\begin{array}{c}-1.738 * * * \\
(-2.98)\end{array}$ & $\begin{array}{c}-0.830^{*} \\
(-1.78)\end{array}$ & $\begin{array}{c}-1.728 * * * \\
(-2.91)\end{array}$ & $\begin{array}{l}-0.754 \\
(-1.60)\end{array}$ \\
\hline$W C_{i}$ & $\begin{array}{l}0.551 \\
(0.87)\end{array}$ & $\begin{array}{l}-0.338 \\
(-0.74)\end{array}$ & $\begin{array}{l}0.826 \\
(1.34)\end{array}$ & $\begin{array}{l}-0.677 \\
(-1.45)\end{array}$ \\
\hline$\left(R E_{i} / T A_{i}\right)$ & $\begin{array}{l}-0.136 \\
(-1.19)\end{array}$ & $\begin{array}{l}-0.049 \\
(-1.58)\end{array}$ & $\begin{array}{l}0.321^{*} \\
(1.84)\end{array}$ & $\begin{array}{l}0.022 \\
(0.81)\end{array}$ \\
\hline$\left(E B I T_{i} / T A_{i}\right)$ & $\begin{array}{l}0.903 \\
(0.77)\end{array}$ & & $\begin{array}{l}0.476 \\
(0.42)\end{array}$ & \\
\hline$\left(M V E_{i} / T L_{i}\right)$ & $\begin{array}{l}-0.017 \\
(-1.33)\end{array}$ & $\begin{array}{l}-0.011 \\
(-0.99)\end{array}$ & $\begin{array}{l}-0.005 \\
(-0.56)\end{array}$ & $\begin{array}{l}-0.002 \\
(-0.32)\end{array}$ \\
\hline$\left(S A L E S_{i} / T A_{i}\right)$ & $\begin{array}{l}-0.242 \\
(-1.16)\end{array}$ & $\begin{array}{l}-0.048 \\
(-0.26)\end{array}$ & $\begin{array}{c}-0.332 * \\
(-1.70)\end{array}$ & $\begin{array}{l}-0.038 \\
(-0.22)\end{array}$ \\
\hline$\triangle R O A_{i}$ & $\begin{array}{c}-3.566^{* *} \\
(-2.30)\end{array}$ & $\begin{array}{l}-1.049 \\
(-1.21)\end{array}$ & $\begin{array}{c}2.047^{*} \\
(1.86)\end{array}$ & $\begin{array}{l}0.525 \\
(1.10)\end{array}$ \\
\hline $\operatorname{Ln}\left(T A_{i}\right)$ & $\begin{array}{l}0.096 \\
(1.14)\end{array}$ & $\begin{array}{l}0.023 \\
(0.32)\end{array}$ & $\begin{array}{l}0.078 \\
(0.91)\end{array}$ & $\begin{array}{l}0.030 \\
(0.42)\end{array}$ \\
\hline$D A_{i}($ Mod. Jones of year $t-1$ or $t)$ & $\begin{array}{c}-8.245 * * * \\
(-4.62)\end{array}$ & & $\begin{array}{c}-13.024 * * * \\
(-5.16)\end{array}$ & \\
\hline$D A_{i}($ Kothari-ROA of year $t-1$ or $t)$ & & $\begin{array}{c}-1.872^{*} \\
(-1.91)\end{array}$ & & $\begin{array}{c}-2.935^{* * *} \\
(-2.32)\end{array}$ \\
\hline Pseudo $R^{2}$ & 0.203 & 0.022 & 0.297 & 0.029 \\
\hline Wald $\chi^{2}$ & $27.920 * * *$ & 7.220 & $32.090 * * *$ & 9.960 \\
\hline No. Obs. & 359 & 322 & 344 & 330 \\
\hline
\end{tabular}


Table 6: The Table reports average cumulative abnormal returns (ACAR) across all non-financial U.S.-listed firms that have publicly announced an intention to be acquired between 1990 and 2009, for different event periods around the announcement day (day 0). In Panels A and B, firm and market returns [-240,-31] and [-340,-31] days prior to the announcement day respectively, are used in order to estimate the market model parameters, for inferring event-period firm abnormal returns. The standardized cross-sectional z statistic (SCS z-stat) of Boehmer et al. (1991), which accounts for event-induced changes in return variance, is used in determining the statistical significance of ACAR. An *,** and $* * *$ indicates that the null hypothesis of a zero average is rejected at the $10 \%, 5 \%$ and $1 \%$ level of significance respectively.

Panel A: Estimation period is [-240, -31] days prior the announcement day (day 0)

\begin{tabular}{|c|c|c|c|c|c|c|c|c|c|}
\hline $\begin{array}{l}\text { Pre-announcement } \\
\text { event period }\end{array}$ & {$[-10,0]$} & {$[-10,+10]$} & {$[-5,0]$} & {$[-5,+5]$} & {$[-1,+1]$} & {$[-1,0]$} & {$[0,+1]$} & {$[0,+5]$} & {$[0,+10]$} \\
\hline \multicolumn{10}{|c|}{ Value-weighted CRSP index used as market proxy } \\
\hline ACAR & $-1.70 \%$ & $1.49 \%$ & $0.69 \% * *$ & $2.49 \% *$ & $1.18 \% * *$ & $1.25 \% * * *$ & $-0.42 \%$ & $1.48 \%$ & $2.90 \% *$ \\
\hline SCS z-stat & 0.916 & 1.386 & 1.972 & 1.674 & 2.490 & 2.857 & 1.568 & 1.391 & 1.804 \\
\hline \multicolumn{10}{|c|}{ Equally-weighted CRSP index used as market proxy } \\
\hline ACAR & $-1.57 \%$ & $1.63 \% *$ & $0.89 \% * *$ & $2.83 \% * *$ & $1.21 \% * *$ & $1.27 \% * * *$ & $-0.41 \%$ & $1.63 \%$ & $2.90 \% *$ \\
\hline SCS z-stat & 1.155 & 1.690 & 2.166 & 1.975 & 2.470 & 2.860 & 1.547 & 1.518 & 1.864 \\
\hline
\end{tabular}

Panel B: Estimation period is $[-340,-31]$ days prior the announcement day (day 0)

\begin{tabular}{|c|c|c|c|c|c|c|c|c|c|}
\hline $\begin{array}{l}\text { Pre-announcement } \\
\text { event period }\end{array}$ & {$[-10,0]$} & {$[-10,+10]$} & {$[-5,0]$} & {$[-5,+5]$} & {$[-1,+1]$} & {$[-1,0]$} & {$[0,+1]$} & {$[0,+5]$} & {$[0,+10]$} \\
\hline \multicolumn{10}{|c|}{ Value-weighted CRSP index used as market proxy } \\
\hline ACAR & $-1.65 \%$ & $1.56 \%$ & $0.69 \% * *$ & $2.47 \% *$ & $1.17 \% * *$ & $1.24 \% * * *$ & $-0.42 \%$ & $1.45 \%$ & $2.90 \% *$ \\
\hline SCS z-stat & 0.811 & 1.351 & 1.988 & 1.729 & 2.482 & 2.901 & 1.559 & 1.460 & 1.853 \\
\hline \multicolumn{10}{|c|}{ Equally-weighted CRSP index used as market proxy } \\
\hline ACAR & $-1.55 \%$ & $1.64 \%$ & $0.90 \% * *$ & $2.82 \% * *$ & $1.18 \% * *$ & $1.25 \% * * *$ & $-0.43 \%$ & $1.58 \%$ & $2.87 \% *$ \\
\hline SCS z-stat & 0.983 & 1.580 & 2.178 & 2.021 & 2.470 & 2.910 & 1.531 & 1.577 & 1.902 \\
\hline
\end{tabular}


Table 7: The Table reports the estimation results of the pooled regression

$C A R_{i}=\delta_{0}+\delta_{1} \operatorname{Lev}_{i}+\delta_{2} \operatorname{Ln}\left(T A_{i}\right)+\delta_{3} Q_{i}+\delta_{4} Z_{i}+\delta_{5}\left(E B I T_{i} / T A_{i}\right)+\delta_{6} D A_{i}+\delta_{7} N o n D E_{i}+e_{i}$

The dependent variable $C A R_{i}$ is the cumulative abnormal return of firm $i$ around the 'seeking buyer' announcement day. Lev $i$ is the leverage of firm $i$, calculated as total debt over total assets, while $\operatorname{Ln}\left(T A_{i}\right)$ is the natural logarithm of firm's $i$ total assets. $Q_{i}$ and $Z_{i}$ are the firm's Tobin Q and its Altman's Z-score respectively. (EBIT $T_{i} / T A_{i}$ ) is the firm's earnings before interest and tax, over total assets. $D A_{i}$ and $N o n D E_{i}$ stand for the firm's discretionary accruals and nondiscretionary earnings respectively. All independent variables except for $D A_{i}$ and $N o n D E_{i}$ are as of year $t$ (the year of the 'seeking buyer' announcement), and t-statistics are reported in parentheses. In Panels A and B, firm and market returns [-240,-31] and [-340,-31] days prior to the announcement day respectively, are used in order to estimate the market model parameters, for inferring event-window firm abnormal returns. The Table reports results for discretionary accruals calculated from the Modified Jones model (specifications (1), (2), (5) and (6)) and the Kothari ROA-matched model (specifications (3), (4), (7) and (8)). In specifications (1), (3), (5) and (7) nondiscretionary earnings $N o n D E_{i}$ are excluded from the regression. An *,** and *** indicates statistical significance at the $10 \%, 5 \%$ and $1 \%$ level.

Panel A: Estimation window for the calculation of CAR is $[-240,-31]$ days prior the announcement day (day 0)

\begin{tabular}{|c|c|c|c|c|c|c|c|c|}
\hline Dependent var. & \multicolumn{4}{|c|}{ CAR $[0,+5]$} & \multicolumn{4}{|c|}{ CAR $[-5,+5]$} \\
\hline Model & $\begin{array}{c}\text { (1) } \\
\text { Mod. Jones } \\
\text { DA } \\
\end{array}$ & $\begin{array}{c}(2) \\
\text { Mod. Jones DA } \\
\text { and NonDE }\end{array}$ & $\begin{array}{c}\text { (3) } \\
\text { Kothari ROA-matched } \\
\text { DA }\end{array}$ & $\begin{array}{c}\text { (4) } \\
\text { Kothari ROA-matched } \\
\text { DA and NonDE }\end{array}$ & $\begin{array}{c}(5) \\
\text { Mod. Jones } \\
\text { DA } \\
\end{array}$ & $\begin{array}{c}(6) \\
\text { Mod. Jones DA } \\
\text { and NonDE }\end{array}$ & $\begin{array}{c}\text { (7) } \\
\text { Kothari ROA-matched } \\
\text { DA }\end{array}$ & $\begin{array}{c}(8) \\
\text { Kothari ROA-matched } \\
\text { DA and NonDE }\end{array}$ \\
\hline Intercept & $\begin{array}{l}0.067 \\
(2.06)\end{array}$ & $\begin{array}{l}0.066 \\
(1.01)\end{array}$ & $\begin{array}{l}0.064^{*} \\
(1.90)\end{array}$ & $\begin{array}{l}0.125^{*} \\
(1.91)\end{array}$ & $\begin{array}{l}0.078 \\
(1.09)\end{array}$ & $\begin{array}{l}0.078 \\
(1.08)\end{array}$ & $\begin{array}{l}0.141^{*} \\
(1.92)\end{array}$ & $\begin{array}{l}0.143^{*} \\
(1.94)\end{array}$ \\
\hline$L e v_{i}$ & $\begin{array}{c}-0.134 * \\
(-1.78)\end{array}$ & $\begin{array}{c}-0.143 * \\
(-1.85)\end{array}$ & $\begin{array}{c}-0.173 * * \\
(-2.57)\end{array}$ & $\begin{array}{c}-0.187 * * \\
(-2.64)\end{array}$ & $\begin{array}{l}-0.132 \\
(-1.64)\end{array}$ & $\begin{array}{c}-0.137 * \\
(-1.68)\end{array}$ & $\begin{array}{c}-0.173 * * \\
(-2.42)\end{array}$ & $\begin{array}{c}-0.180 * * \\
(-2.40)\end{array}$ \\
\hline $\operatorname{Ln}\left(T A_{i}\right)$ & $\begin{array}{l}0.003 \\
(0.31)\end{array}$ & $\begin{array}{l}0.003 \\
(0.30)\end{array}$ & $\begin{array}{l}-0.003 \\
(-0.32)\end{array}$ & $\begin{array}{l}-0.004 \\
(-0.37)\end{array}$ & $\begin{array}{l}0.001 \\
(0.10)\end{array}$ & $\begin{array}{l}0.001 \\
(0.10)\end{array}$ & $\begin{array}{l}-0.007 \\
(-0.66)\end{array}$ & $\begin{array}{l}-0.007 \\
(-0.68)\end{array}$ \\
\hline$Q_{i}$ & $\begin{array}{l}-0.009 \\
(-1.09)\end{array}$ & $\begin{array}{l}-0.009 \\
(-0.99)\end{array}$ & $\begin{array}{l}-0.002 \\
(-0.28)\end{array}$ & $\begin{array}{l}-0.000 \\
(-0.03)\end{array}$ & $\begin{array}{l}-0.010 \\
(-0.92)\end{array}$ & $\begin{array}{l}-0.010 \\
(-0.86)\end{array}$ & $\begin{array}{l}-0.002 \\
(-0.21)\end{array}$ & $\begin{array}{l}-0.001 \\
(-0.12)\end{array}$ \\
\hline$Z_{i}$ & $\begin{array}{l}0.003 \\
(0.51)\end{array}$ & $\begin{array}{l}0.003 \\
(0.51)\end{array}$ & $\begin{array}{l}-0.005 \\
(-0.79)\end{array}$ & $\begin{array}{l}-0.005 \\
(-0.91)\end{array}$ & $\begin{array}{l}0.003 \\
(0.48)\end{array}$ & $\begin{array}{l}0.003 \\
(0.47)\end{array}$ & $\begin{array}{l}-0.006 \\
(-1.07)\end{array}$ & $\begin{array}{l}-0.006 \\
(-1.09)\end{array}$ \\
\hline$\left(E B I T_{i} / T A_{i}\right)$ & $\begin{array}{c}-0.183 * \\
(-1.75)\end{array}$ & $\begin{array}{c}-0.199 * \\
(-1.89)\end{array}$ & & & $\begin{array}{c}-0.212 * \\
(-1.80)\end{array}$ & $\begin{array}{c}-0.219 * \\
(-1.87)\end{array}$ & & \\
\hline $\begin{array}{l}D A_{i} \\
\text { (As of year } t-1)\end{array}$ & $\begin{array}{c}0.076 * * \\
(2.05)\end{array}$ & $\begin{array}{c}0.075 * * \\
(2.05)\end{array}$ & $\begin{array}{l}0.216^{*} \\
(1.69)\end{array}$ & $\begin{array}{l}0.243^{*} \\
(1.77)\end{array}$ & $\begin{array}{c}0.108 * * \\
(2.50)\end{array}$ & $\begin{array}{c}0.107 * * \\
(2.43)\end{array}$ & $\begin{array}{l}0.257 \\
(1.52)\end{array}$ & $\begin{array}{l}0.314 * \\
(1.74)\end{array}$ \\
\hline $\begin{array}{l}N o n D E_{i} \\
(\text { As of year } t-1)\end{array}$ & & $\begin{array}{l}0.037 \\
(0.80)\end{array}$ & & $\begin{array}{l}0.044 \\
(0.88)\end{array}$ & & $\begin{array}{l}0.018 \\
(0.34)\end{array}$ & & $\begin{array}{l}0.022 \\
(0.29)\end{array}$ \\
\hline$R^{2}$ & 0.144 & 0.148 & 0.154 & 0.158 & 0.153 & 0.154 & 0.150 & 0.150 \\
\hline$F$ & $2.61 * *$ & $2.68 * *$ & $2.34 * *$ & $1.97 *$ & $1.99 *$ & $2.27 * *$ & 1.66 & 1.61 \\
\hline No. Obs. & 90 & 90 & 79 & 79 & 90 & 90 & 79 & 79 \\
\hline
\end{tabular}


Panel B: Estimation window for the calculation of CAR is $[-340,-31]$ days prior the announcement day (day 0 )

\begin{tabular}{|c|c|c|c|c|c|c|c|c|}
\hline Dependent var. & \multicolumn{4}{|c|}{ CAR $[0,+5]$} & \multicolumn{4}{|c|}{ CAR $[-5,+5]$} \\
\hline Model & $\begin{array}{c}(1) \\
\text { Mod. Jones } \\
\text { DA }\end{array}$ & $\begin{array}{c}(2) \\
\text { Mod. Jones DA } \\
\text { and NonDE }\end{array}$ & $\begin{array}{c}\text { (3) } \\
\text { Kothari ROA-matched } \\
\text { DA }\end{array}$ & $\begin{array}{c}(4) \\
\text { Kothari ROA-matched } \\
\text { DA and NonDE }\end{array}$ & $\begin{array}{c}(5) \\
\text { Mod. Jones } \\
\text { DA } \\
\end{array}$ & $\begin{array}{c}(6) \\
\text { Mod. Jones DA } \\
\text { and NonDE }\end{array}$ & $\begin{array}{c}(7) \\
\text { Kothari ROA-matched } \\
\text { DA }\end{array}$ & $\begin{array}{c}(8) \\
\text { Kothari ROA-matched } \\
\text { DA and NonDE }\end{array}$ \\
\hline Intercept & $\begin{array}{l}0.067 \\
(1.05)\end{array}$ & $\begin{array}{l}0.067 \\
(1.03)\end{array}$ & $\begin{array}{c}0.126 * * \\
(2.01)\end{array}$ & $\begin{array}{c}0.130 * * \\
(2.02)\end{array}$ & $\begin{array}{l}0.081 \\
(1.13)\end{array}$ & $\begin{array}{l}0.080 \\
(1.12)\end{array}$ & $\begin{array}{c}0.151^{* *} \\
(2.08)\end{array}$ & $\begin{array}{c}0.153 * * \\
(2.10)\end{array}$ \\
\hline $\operatorname{Lev}_{i}$ & $\begin{array}{c}-0.133 * \\
(-1.75)\end{array}$ & $\begin{array}{l}-0.142^{*} \\
(-1.83)\end{array}$ & $\begin{array}{c}-0.172 * * \\
(-2.53)\end{array}$ & $\begin{array}{c}-0.186 * * \\
(-2.60)\end{array}$ & $\begin{array}{l}-0.131 \\
(-1.60)\end{array}$ & $\begin{array}{l}-0.137 * \\
(-1.67)\end{array}$ & $\begin{array}{c}-0.171 * * \\
(-2.34)\end{array}$ & $\begin{array}{c}-0.180 * * \\
(-2.37)\end{array}$ \\
\hline $\operatorname{Ln}\left(T A_{i}\right)$ & $\begin{array}{l}0.003 \\
(0.29)\end{array}$ & $\begin{array}{l}0.003 \\
(0.29)\end{array}$ & $\begin{array}{l}-0.004 \\
(-0.40)\end{array}$ & $\begin{array}{l}-0.005 \\
(-0.45)\end{array}$ & $\begin{array}{l}0.001 \\
(0.06)\end{array}$ & $\begin{array}{l}0.001 \\
(0.05)\end{array}$ & $\begin{array}{l}-0.009 \\
(-0.79)\end{array}$ & $\begin{array}{l}-0.009 \\
(-0.82)\end{array}$ \\
\hline$Q_{i}$ & $\begin{array}{l}-0.009 \\
(-1.05)\end{array}$ & $\begin{array}{l}-0.009 \\
(-0.96)\end{array}$ & $\begin{array}{c}-0.002 \\
(-0.27)\end{array}$ & $\begin{array}{l}-0.000 \\
(-0.02)\end{array}$ & $\begin{array}{l}-0.010 \\
(-0.89)\end{array}$ & $\begin{array}{l}-0.010 \\
(-0.82)\end{array}$ & $\begin{array}{l}-0.003 \\
(-0.24)\end{array}$ & $\begin{array}{l}-0.001 \\
(-0.11)\end{array}$ \\
\hline$Z_{i}$ & $\begin{array}{l}0.004 \\
(0.53)\end{array}$ & $\begin{array}{l}0.003 \\
(0.53)\end{array}$ & $\begin{array}{l}-0.004 \\
(-0.76)\end{array}$ & $\begin{array}{l}-0.005 \\
(-0.89)\end{array}$ & $\begin{array}{l}0.003 \\
(0.51)\end{array}$ & $\begin{array}{l}0.003 \\
(0.50)\end{array}$ & $\begin{array}{l}-0.005 \\
(-1.01)\end{array}$ & $\begin{array}{l}-0.006 \\
(-1.06)\end{array}$ \\
\hline$\left(E B I T_{i} / T A_{i}\right)$ & $\begin{array}{l}-0.185^{*} \\
(-1.75)\end{array}$ & $\begin{array}{l}-0.201^{*} \\
(-1.90)\end{array}$ & & & $\begin{array}{l}-0.212 * \\
(-1.76)\end{array}$ & $\begin{array}{l}-0.223^{*} \\
(-1.88)\end{array}$ & & \\
\hline $\begin{array}{l}D A_{i} \\
\text { (As of year } t-I \text { ) }\end{array}$ & $\begin{array}{c}0.075^{* *} \\
(2.01)\end{array}$ & $\begin{array}{c}0.074 * \\
(1.98)\end{array}$ & $\begin{array}{l}0.221^{*} \\
(1.70)\end{array}$ & $\begin{array}{l}0.249^{*} \\
(1.77)\end{array}$ & $\begin{array}{c}0.103 * * \\
(2.36)\end{array}$ & $\begin{array}{c}0.103 * * \\
(2.28)\end{array}$ & $\begin{array}{l}0.259 \\
(1.50)\end{array}$ & $\begin{array}{l}0.276 \\
(1.52)\end{array}$ \\
\hline $\begin{array}{l}N \text { (As of year } t-1 \text { ) } \\
\text { (As yes }\end{array}$ & & $\begin{array}{l}0.039 \\
(0.83)\end{array}$ & & $\begin{array}{l}0.044 \\
(0.88)\end{array}$ & & $\begin{array}{l}0.026 \\
(0.48)\end{array}$ & & $\begin{array}{l}0.028 \\
(0.37)\end{array}$ \\
\hline$R^{2}$ & 0.143 & 0.147 & 0.155 & 0.159 & 0.145 & 0.146 & 0.146 & 0.147 \\
\hline$F$ & $2.54 * *$ & $2.64 * *$ & $2.29^{*}$ & $1.92 *$ & $1.85^{*}$ & $2.23 * *$ & 1.61 & 1.38 \\
\hline No. Obs. & 90 & 90 & 79 & 79 & 90 & 90 & 79 & 79 \\
\hline
\end{tabular}


Table 8: The Table reports the number of non-financial U.S.-listed firms that have publicly announced an intention to be acquired, which were subsequently acquired within a period of 2 years. The Table additionally reports information on the mean, median, minimum, maximum, and standard deviation of deal size and percentage acquired.

\begin{tabular}{lccccc}
\hline No. of firms & & & & & \\
\hline Seeking buyer: & & 248 & & & \\
Subsequently acquired (within 2 years): & 69 & & & \\
\hline \multicolumn{7}{l}{} & & & & & \\
\hline Acquisition statistics & Average & Median & Minimum & Maximum & St. Dev. \\
\hline Deal Size (in mil. \$) & 283.56 & 46.00 & 0.13 & $3,270.30$ & 676.72 \\
Percent acquired (\%) & 96.98 & 100.00 & 33.33 & 100.00 & 11.65 \\
\hline
\end{tabular}


Table 9: The Table reports the estimation results of the pooled logit regression

$S B A C Q_{i}=\zeta_{0}+\zeta_{1} L e v_{i}+\zeta_{2} C R_{i}+\zeta_{3} \operatorname{Ln}\left(T A_{i}\right)+\zeta_{4} Q_{i}+\zeta_{5} Z_{i}+\zeta_{6}\left(E B I T_{i} / T A_{i}\right)+\zeta_{7} D A_{i}+\zeta_{8} N_{o n D E}+e_{i}$

The dependent variable $S B A C Q_{i}$ is a dummy variable that takes the value of one if firm $i$, that has issued a public 'seeking buyer' announcement between 1990 and 2009, is subsequently acquired within a period of two years, and zero otherwise. $L e v_{i}$ is the leverage of firm $i$, calculated as total debt over total assets. $C R_{i}$ is the current ratio of firm $i$, while $\operatorname{Ln}\left(T A_{i}\right)$ is the natural logarithm of firm's $i$ total assets. $Q_{i}$ and $Z_{i}$ are the firm's Tobin Q and its Altman's Z-score respectively. (EBIT $i$ $T A_{i}$ ) is the firm's earnings before interest and tax, over total assets. $D A_{i}$ and $N o n D E_{i}$ stand for the firm's discretionary accruals and nondiscretionary earnings respectively. All independent variables are as of year $t$ (the year of the 'seeking buyer' announcement), and t-statistics are reported in parentheses. The Table reports results for discretionary accruals calculated from the Jones model (specifications (1) and (4)), the Modified Jones model (specifications (2) and (5)) and the Kothari ROA-matched model (specifications (3) and (6)). In specifications (4)-(6) the nondiscretionary earnings are excluded from the regression.

\begin{tabular}{|c|c|c|c|c|c|c|}
\hline Specification & $\begin{array}{c}(1) \\
\text { Jones DA } \\
\text { and } \\
\text { NonDE in } \\
\text { regressors }\end{array}$ & $\begin{array}{c}(2) \\
\text { Mod. Jones DA } \\
\text { and NonDE in } \\
\text { regressors }\end{array}$ & $\begin{array}{c}(3) \\
\text { Kothari ROA- } \\
\text { matched DA } \\
\text { and NonDE in } \\
\text { regressors }\end{array}$ & $\begin{array}{l}(4) \\
\text { Jones DA in } \\
\text { regressors }\end{array}$ & $\begin{array}{c}(5) \\
\text { Mod. Jones DA } \\
\text { in regressors }\end{array}$ & $\begin{array}{c}(6) \\
\text { Kothari ROA- } \\
\text { matched DA in } \\
\text { regressors }\end{array}$ \\
\hline Intercept & $\begin{array}{c}-3.047 * * \\
(-2.15)\end{array}$ & $\begin{array}{c}-3.568 * * \\
(-2.29)\end{array}$ & $\begin{array}{c}-5.460 * * * \\
(-2.70)\end{array}$ & $\begin{array}{c}-2.988 * * \\
(-2.17)\end{array}$ & $\begin{array}{c}-3.807 * * \\
(-2.39)\end{array}$ & $\begin{array}{c}-5.203 * * * \\
(-2.67)\end{array}$ \\
\hline$L e v_{i}$ & $\begin{array}{l}-0.514 \\
(-0.56)\end{array}$ & $\begin{array}{c}-2.213 * * \\
(-1.98)\end{array}$ & $\begin{array}{l}-2.053 \\
(-1.63)\end{array}$ & $\begin{array}{l}-0.536 \\
(-0.59)\end{array}$ & $\begin{array}{l}-2.079 * \\
(-1.68)\end{array}$ & $\begin{array}{l}-1.578 \\
(-1.14)\end{array}$ \\
\hline$C R_{i}$ & $\begin{array}{l}0.054 \\
(0.26)\end{array}$ & $\begin{array}{l}0.246 \\
(1.15)\end{array}$ & $\begin{array}{l}0.193 \\
(0.90)\end{array}$ & $\begin{array}{l}0.069 \\
(0.34)\end{array}$ & $\begin{array}{l}0.184 \\
(0.88)\end{array}$ & $\begin{array}{l}0.069 \\
(0.29)\end{array}$ \\
\hline $\operatorname{Ln}\left(T A_{i}\right)$ & $\begin{array}{l}0.312^{*} \\
(1.67)\end{array}$ & $\begin{array}{c}0.449 * * \\
(2.26)\end{array}$ & $\begin{array}{c}0.605^{* *} \\
(2.47)\end{array}$ & $\begin{array}{c}0.303^{*} \\
(1.67)\end{array}$ & $\begin{array}{c}0.499 * * \\
(2.42)\end{array}$ & $\begin{array}{c}0.639 * * * \\
(2.63)\end{array}$ \\
\hline$Q_{i}$ & $\begin{array}{l}0.291^{*} \\
(1.65)\end{array}$ & $\begin{array}{l}0.507^{* *} \\
(2.17)\end{array}$ & $\begin{array}{c}0.570^{* *} \\
(2.27)\end{array}$ & $\begin{array}{c}0.307^{*} \\
(1.81)\end{array}$ & $\begin{array}{c}0.446^{* *} \\
(2.09)\end{array}$ & $\begin{array}{l}0.413^{* *} \\
(2.10)\end{array}$ \\
\hline$Z_{i}$ & $\begin{array}{l}-0.247^{*} \\
(-1.86)\end{array}$ & $\begin{array}{c}-0.471 * * * \\
(-2.69)\end{array}$ & $\begin{array}{c}-0.374 * * * \\
(-3.12)\end{array}$ & $\begin{array}{c}-0.255^{* *} \\
(-1.96)\end{array}$ & $\begin{array}{c}-0.406 * * \\
(-2.39)\end{array}$ & $\begin{array}{c}-0.244 * * * \\
(-2.83)\end{array}$ \\
\hline$\left(E B I T_{i} / T A_{i}\right)$ & $\begin{array}{l}3.281 \\
(1.29)\end{array}$ & $\begin{array}{l}3.105 \\
(0.89)\end{array}$ & & $\begin{array}{l}2.980 \\
(1.26)\end{array}$ & $\begin{array}{l}3.600 \\
(1.18)\end{array}$ & \\
\hline$D A_{i}($ Jones of year $t)$ & $\begin{array}{l}3.471 \\
(1.61)\end{array}$ & & & $\begin{array}{l}3.808^{*} \\
(1.81)\end{array}$ & & \\
\hline$N o n D E_{i}($ Jones of year $t)$ & $\begin{array}{l}-0.675 \\
(-0.38)\end{array}$ & & & & & \\
\hline$D A_{i}($ Mod. Jones of year $t)$ & & $\begin{array}{c}4.241 * \\
(1.77)\end{array}$ & & & $\begin{array}{l}2.733 \\
(1.31)\end{array}$ & \\
\hline $\begin{array}{l}N_{t} \text { ) } \\
\text { D E } E_{i} \text { (Mod. Jones of year }\end{array}$ & & $\begin{array}{l}2.266 \\
(0.75)\end{array}$ & & & & \\
\hline$D A_{i}($ Kothari-ROA of year $t)$ & & & $\begin{array}{l}8.768 * * * \\
(2.69)\end{array}$ & & & $\begin{array}{c}5.844 * * \\
(1.96)\end{array}$ \\
\hline $\begin{array}{l}N o n D E_{i} \text { (Kothari-ROA of } \\
\text { year } t \text { ) }\end{array}$ & & & $\begin{array}{l}3.642 \\
(1.34)\end{array}$ & & & \\
\hline Pseudo $R^{2}$ & 0.118 & 0.188 & 0.205 & 0.118 & 0.180 & 0.183 \\
\hline Wald $\chi^{2}$ & 9.48 & 12.86 & $13.94 *$ & 9.37 & $12.33^{*}$ & $11.36^{*}$ \\
\hline No. Obs. & 112 & 99 & 97 & 112 & 99 & 97 \\
\hline
\end{tabular}




\title{
Appendices
}

\section{Appendix A: Examples of 'seeking buyer' announcements}

In this Appendix we provide examples of typical 'seeking buyer' announcements in our sample. A typical example of such announced plans is given by the following news release by Contango Oil \& Gas Company on November 6, 2007:

“CONTANGO OIL \& GAS COMPANY

NEWS RELEASE

\section{Contango Engages Merrill Lynch to Assist in Review of Strategic}

\begin{abstract}
Alternatives
HOUSTON, TX - Contango Oil \& Gas Company (AMEX:MCF) announced today that its Board of Directors is in the process of reviewing a range of strategic alternatives to enhance shareholder value, including the possible sale or merger of the Company, the sale of its Arkansas Fayetteville Shale interest, the sale of its Freeport LNG partnership interest, the sale of other significant assets and changes to the Company's business plan.

Contango has retained Merrill Lynch \& Co. to provide financial advisory services in connection with its review. There is no assurance that the review of strategic alternatives will result in Contango changing its business plan, pursuing any particular transaction, if any, or, if it pursues any such transaction, that it will be completed. Contango does not expect to make further public comment regarding the review until the Board of Directors has approved a specific transaction or course of action or otherwise deems disclosure of significant developments is appropriate."
\end{abstract}

A similar, more recent announcement by NASDAQ firm Spansion Inc., reads: 
"SUNNYVALE, Calif., Jan 15, 2009 - Spansion Inc. (Nasdaq: SPSN) announced today that it has been exploring strategic alternatives, including, but not limited to, opportunities to merge with or sell to similar U.S. or foreign businesses. These strategic alternatives would be designed to build on Spansion's position as a leading supplier of NOR flash memory by creating significantly greater scale and to provide Spansion's customers with a broader range of more cost effective memory solutions. Spansion has engaged Barclays Capital to assist the company in exploring these strategic alternatives."

Virtually all 368 announcements in our sample are of the same phrasing. Strategic considerations are highlighted as the main motive behind the decision to openly look for a merger or acquisition partner. 


\section{Appendix B: Definitions of variables used}

This Appendix summarizes the definitions of the financial variables that are reported in Table

1, for the SB firms and the two matched samples.

\begin{tabular}{|c|c|c|}
\hline Financial Variable & Description & Compustat item calculation \\
\hline Total Assets (TA) & Total assets in million dollars & \#6 \\
\hline Sales & Sales in million dollars & $\# 12$ \\
\hline ROA & $\begin{array}{l}\text { Return on Assets, calculated as Net Income } \\
\text { before extraordinary items, divided by lagged } \\
\text { Total Assets }\end{array}$ & \#123/lagged\#6 \\
\hline$\Delta \mathrm{ROA}$ & Change in ROA & $\begin{array}{l}(\# 123 / \text { lagged\#6) })_{t}- \\
(\# 123 / \text { lagged\#6) })_{t-1}\end{array}$ \\
\hline EBIT/Total Assets & $\begin{array}{l}\text { Earnings Before Interest and Tax, divided by } \\
\text { Total Assets }\end{array}$ & $(\# 13-\# 14) / \# 6$ \\
\hline CFO/Total Assets & $\begin{array}{l}\text { Cash Flow from Operations, divided by Total } \\
\text { Assets }\end{array}$ & \#308/\#6 \\
\hline R\&D Expense/Total Assets & $\begin{array}{l}\text { Research and Development Expenditure, divided } \\
\text { by Total Assets }\end{array}$ & \#46/\#6 \\
\hline PP\&E/Total Assets & $\begin{array}{l}\text { Property, Plant and Equipment, divided by Total } \\
\text { Assets }\end{array}$ & \#7/\#6 \\
\hline Cap. Exp./Total Assets & Capital Expenditures, divided by Total Assets & \#128/\#6 \\
\hline Current Ratio & Current Assets, divided by Current Liabilities & \#4/\#5 \\
\hline Quick Ratio & $\begin{array}{l}\text { Current Assets minus Inventory, over Current } \\
\text { Liabilities }\end{array}$ & $(\# 4-\# 3) / \# 5$ \\
\hline Long term Debt/Total Assets & Long Term Debt, divided by Total Assets & \#9/\#6 \\
\hline Total Debt/Total Assets & Total Debt, divided by Total Assets & $(\# 9+\# 34) / \# 6$ \\
\hline Sales Growth (SGR) & Percentage annual change in Sales & (\#12-lagged\#12)/ lagged\#12 \\
\hline Tobin's Q & $\begin{array}{l}\text { The sum of Book Value of Debt and Market } \\
\text { Value of Equity, divided by Total Assets }\end{array}$ & $(\# 9+\# 34+\# 199 * \# 25) / \# 6$ \\
\hline Market-to-Book & $\begin{array}{l}\text { Market Value of Equity (calculated as closing } \\
\text { stock price at fiscal year-end times number of } \\
\text { shares outstanding), divided by Book Value of } \\
\text { Equity }\end{array}$ & $(\# 199 * \# 25) / \# 60$ \\
\hline \multirow[t]{4}{*}{ Altman's Z score } & $\begin{array}{l}\text { Altman's (1968) Z-score has been calculated as } \\
\text { in Zhao and Chen (2008a), based on Begley et } \\
\text { al. (1996): } \\
Z=10.4 \mathrm{X} 1+1.0 \mathrm{X} 2+10.6 \mathrm{X} 3+0.3 \mathrm{X} 4-0.17 \mathrm{X} 5\end{array}$ & $\begin{array}{l}\text { X1 = Working Capital/TA } \\
(\# 179 / \# 6), \\
\text { X2 = Retained Earnings/TA } \\
(\# 36 / \# 6),\end{array}$ \\
\hline & & $\begin{array}{l}\mathrm{X} 3=\mathrm{EBIT} / \mathrm{TA} \\
(\# 13-\# 14) / \# 6\end{array}$ \\
\hline & & $\begin{array}{l}\text { X4 = market equity/total } \\
\text { liabilities }((\# 199 * \# 25) / \# 181)\end{array}$ \\
\hline & & $\begin{array}{l}\mathrm{X} 5=\text { Sales/TA } \\
(\# 12 / \# 6)\end{array}$ \\
\hline
\end{tabular}




\section{Appendix C}

In this appendix, we summarize in Table C.1 on the next page results from the estimation of equation (3), when the growth and distress adjusted discretionary accruals are used as independent variables on the right-hand side, instead of the 'unadjusted' accruals. When growth-adjusted (respectively distress-adjusted) discretionary accruals are used, the growth (distress) control variables are excluded from the right-hand side. 
Table C.1: The Table reports the estimation results of the pooled logit regression

$$
\begin{gathered}
S B_{i}=\gamma_{0}+\gamma_{1}(W C / T A)_{i}+\gamma_{2}\left(R E_{i} / T A_{i}\right)+\gamma_{3}\left(E B I T_{i} / T A_{i}\right)+\gamma_{4}\left(M V E_{i} / T L_{i}\right)+\gamma_{5}\left(S A L E S_{i} / T A_{i}\right)+\gamma_{6} \Delta R O A_{i}+\gamma_{7} \operatorname{Ln}\left(T A_{i}\right) \\
+\gamma_{8} D A_{i}+u_{i}
\end{gathered}
$$

as in Table 5, only the $\triangle \mathrm{ROA}$-adjusted and the Altman Z-adjusted $D A_{i}$ are now used as regressors. When $\triangle$ ROA-adjusted (respectively Altman Z-adjusted) discretionary accruals are used, the growth (distress) control variables are excluded from the right-hand side of the equation. The regression is estimated on the union of two samples, one consisting of all U.S. non-financial listed firms that have issued a 'seeking buyer' (SB) announcement between 1990 and 2009, and a matched sample based on industry and total assets. To construct the matching firms' sample, each SB firm is matched in the year of the SB announcement with two firms from the same 4-digit SIC code based on their total assets. The dependent variable $S B_{i}$ is a dummy variable that takes the value of one if firm $i$ has issued a public 'seeking buyer' announcement between 1990 and 2009, and zero otherwise. $(W C / T A)_{i}$ equals working capital total assets $(T A),\left(R E_{i} / T A_{i}\right)$ is the ratio of retained earnings/TA, $\left(E B I T_{i} / T A_{i}\right)$, and $\left(S A L E S_{i} / T A_{i}\right)$ equals earnings before interest and tax, and sales, respectively, over TA, $\left(M V E_{i} / T A_{i}\right)$ equals MVE over total liabilities, while $\operatorname{Ln}\left(T A_{i}\right)$ is the natural logarithm of firm's $i$ total assets. $\triangle R O A_{i}$ is the firm's change in ROA and $D A_{i}$ stands for the firm's discretionary accruals, adjusted for growth and distress. All independent variables are as of year $t$ (the year of the 'seeking buyer' announcement), and t-statistics are reported in parentheses. An $*, * *$ and $* * *$ indicates statistical significance at the $10 \%, 5 \%$ and $1 \%$ level respectively.

\begin{tabular}{|c|c|c|}
\hline Specification & $\begin{array}{c}(1) \\
\text { Mod. Jones } \\
\Delta \text { ROA-adjusted } \\
\text { DA of year } t \text { in } \\
\text { regressors }\end{array}$ & $\begin{array}{c}\text { (2) } \\
\text { Mod. Jones } \\
\text { Altman Z-adjusted } \\
\text { DA of year } t \text { in } \\
\text { regressors } \\
\end{array}$ \\
\hline Intercept & $\begin{array}{l}-0.979^{*} \\
(-1.92)\end{array}$ & $\begin{array}{c}-1.519 * * * \\
(-3.41)\end{array}$ \\
\hline$\left(W C_{i} / T A_{i}\right)$ & $\begin{array}{l}-0.098 \\
(-0.27)\end{array}$ & \\
\hline$\left(R E_{i} / T A_{i}\right)$ & $\begin{array}{l}0.086 \\
(0.94)\end{array}$ & \\
\hline$\left(E B I T_{i} / T A_{i}\right)$ & $\begin{array}{l}-0.599 \\
(-0.79)\end{array}$ & $\begin{array}{l}-0.315 \\
(-0.56)\end{array}$ \\
\hline$\left(M V E_{i} / T L_{i}\right)$ & $\begin{array}{l}-0.003 \\
(-0.42)\end{array}$ & \\
\hline$\left(S A L E S_{i} / T A_{i}\right)$ & $\begin{array}{l}-0.129 \\
(-0.71)\end{array}$ & \\
\hline$\triangle R O A_{i}$ & & $\begin{array}{l}0.042 \\
(0.56)\end{array}$ \\
\hline $\operatorname{Ln}\left(T A_{i}\right)$ & $\begin{array}{l}0.057 \\
(0.74)\end{array}$ & $\begin{array}{l}0.108 \\
(1.41)\end{array}$ \\
\hline$D A_{i}($ Mod. Jones of year $t-1$ or $t)$ & $\begin{array}{c}-2.627 * * \\
(-2.22)\end{array}$ & \\
\hline$D A_{i}($ Kothari-ROA of year $t-l$ or $t)$ & & $\begin{array}{c}-2.115^{* *} \\
(-2.19)\end{array}$ \\
\hline Pseudo $R^{2}$ & 0.025 & 0.022 \\
\hline Wald $\chi^{2}$ & 8.020 & 7.520 \\
\hline No. Obs. & 320 & 294 \\
\hline
\end{tabular}

Panel A: Nondiscretionary earnings $N o n D E_{i}$ are included in regressors 


\section{Appendix D}

In this appendix, we summarize in Table D.1 on the next page results from the cumulative abnormal returns, with $D A_{i}$ and $N o n D E_{i}$ as of year $t$ and with $C A R_{i}$ for $[0,+1]$ and $[-1,+1]$ as the dependent variable. 
Table D.1: The Table reports the estimation results of the pooled regression

$C A R_{i}=\delta_{0}+\delta_{1} L e v_{i}+\delta_{2} \operatorname{Ln}\left(T A_{i}\right)+\delta_{3} Q_{i}+\delta_{4} Z_{i}+\delta_{5}\left(E B I T_{i} / T A_{i}\right)+\delta_{6} D A_{i}+\delta_{7} N o n D E_{i}+e_{i}$

The dependent variable $C A R_{i}$ is the cumulative abnormal return of firm $i$ around the 'seeking buyer' announcement day. Lev $i$ is the leverage of firm $i$, calculated as total debt over total assets, while $\operatorname{Ln}\left(T A_{i}\right)$ is the natural logarithm of firm's $i$ total assets. $Q_{i}$ and $Z_{i}$ are the firm's Tobin $\mathrm{Q}$ and its Altman's Z-score respectively. (EBIT $\left.T_{i} / T A_{i}\right)$ is the firm's earnings before interest and tax, over total assets. $D A_{i}$ and $N o n D A_{i}$ stand for the firm's discretionary accruals and nondiscretionary earnings respectively. All independent variables are as of year $t$ (the year of the 'seeking buyer' announcement), and t-statistics are reported in parentheses. In Panels A and B, firm and market returns [-240,-31] and [-340,-31] days prior to the announcement day respectively, are used in order to estimate the market model parameters, for inferring event-window firm abnormal returns. The Table reports results for discretionary accruals calculated from the Jones model (specifications (1), (2), (5) and (6)) and the Kothari ROA-matched model (specifications (3), (4), (7) and (8)). In specifications (1), (3), (5) and (7) nondiscretionary earnings $N_{0 n D E}$ are excluded from the regression. An *, ** and *** indicates statistical significance at the $10 \%, 5 \%$ and $1 \%$ level respectively.

Panel A: Estimation window for the calculation of CAR is [-240, -31] days prior the announcement day (day 0)

\begin{tabular}{|c|c|c|c|c|c|c|c|c|}
\hline Dependent var. & & & CAR $[0,+1]$ & & & & CAR $[-1,+1]$ & \\
\hline Model & $\begin{array}{c}(1) \\
\text { Jones DA }\end{array}$ & $\begin{array}{c}(2) \\
\text { Jones DA and } \\
\text { NonDE }\end{array}$ & $\begin{array}{c}\text { (3) } \\
\text { Kothari ROA-matched } \\
\text { DA }\end{array}$ & $\begin{array}{c}(4) \\
\text { Kothari ROA-matched } \\
\text { DA and NonDE }\end{array}$ & $\begin{array}{c}5) \\
\text { Jones DA }\end{array}$ & $\begin{array}{c}6) \\
\text { Jones DA and } \\
\text { NonDE }\end{array}$ & $\begin{array}{c}\text { (7) } \\
\text { Kothari ROA-matched } \\
\text { DA }\end{array}$ & $\begin{array}{c}(8) \\
\text { Kothari ROA-matched } \\
\text { DA and NonDE }\end{array}$ \\
\hline Intercept & $\begin{array}{c}0.187 * * * \\
(2.70)\end{array}$ & $\begin{array}{c}0.183^{* * * *} \\
(2.65)\end{array}$ & $\begin{array}{c}0.143^{* *} \\
(2.38)\end{array}$ & $\begin{array}{c}0.147 * * \\
(2.37)\end{array}$ & $\begin{array}{c}0.170 * * \\
(2.42)\end{array}$ & $\begin{array}{c}0.182^{* *} \\
(2.37)\end{array}$ & $\begin{array}{c}0.149 * * * \\
(2.71)\end{array}$ & $\begin{array}{c}0.146^{* * *} \\
(2.45)\end{array}$ \\
\hline Lev $_{i}$ & $\begin{array}{c}-0.176 * * * \\
(-2.74)\end{array}$ & $\begin{array}{c}-0.175 * * * \\
(-2.69)\end{array}$ & $\begin{array}{c}-0.116^{* * *} \\
(-2.04)\end{array}$ & $\begin{array}{c}-0.119^{* * *} \\
(-2.06)\end{array}$ & $\begin{array}{c}-0.157 * * \\
(-2.09)\end{array}$ & $\begin{array}{c}-0.161^{* *} \\
(-2.08)\end{array}$ & $\begin{array}{c}-0.114 * \\
(-1.76)\end{array}$ & $\begin{array}{l}-0.111 \\
(-1.62)\end{array}$ \\
\hline $\operatorname{Ln}\left(T A_{i}\right)$ & $\begin{array}{c}-0.015^{*} \\
(-1.71)\end{array}$ & $\begin{array}{c}-0.014 * \\
(-1.69)\end{array}$ & $\begin{array}{l}-0.011 \\
(-1.61)\end{array}$ & $\begin{array}{l}-0.012 \\
(-1.59)\end{array}$ & $\begin{array}{l}-0.015 \\
(-1.38)\end{array}$ & $\begin{array}{l}-0.016 \\
(-1.43)\end{array}$ & $\begin{array}{l}-0.012 * \\
(-1.72)\end{array}$ & $\begin{array}{l}-0.011 \\
(-1.38)\end{array}$ \\
\hline$Q_{i}$ & $\begin{array}{l}-0.001 \\
(-0.13)\end{array}$ & $\begin{array}{l}-0.001 \\
(-0.17)\end{array}$ & $\begin{array}{l}-0.008 \\
(-0.98)\end{array}$ & $\begin{array}{l}-0.006 \\
(-0.80)\end{array}$ & $\begin{array}{l}0.003 \\
(0.40)\end{array}$ & $\begin{array}{l}0.005 \\
(0.49)\end{array}$ & $\begin{array}{l}-0.001 \\
(-0.12)\end{array}$ & $\begin{array}{l}-0.002 \\
(-0.24)\end{array}$ \\
\hline$Z_{i}$ & $\begin{array}{l}-0.009 \\
(-1.26)\end{array}$ & $\begin{array}{l}-0.009 \\
(-1.24)\end{array}$ & $\begin{array}{l}-0.001 \\
(-0.29)\end{array}$ & $\begin{array}{l}-0.002 \\
(-0.48)\end{array}$ & $\begin{array}{l}-0.007 \\
(-0.99)\end{array}$ & $\begin{array}{l}-0.007 \\
(-1.04)\end{array}$ & $\begin{array}{l}-0.002 \\
(-0.57)\end{array}$ & $\begin{array}{l}-0.001 \\
(-0.23)\end{array}$ \\
\hline$\left(E B I T_{i} / T A_{i}\right)$ & $\begin{array}{l}0.054 \\
(0.52)\end{array}$ & $\begin{array}{l}0.076 \\
(0.49)\end{array}$ & & & $\begin{array}{l}0.033 \\
(0.27)\end{array}$ & $\begin{array}{l}-0.037 \\
(-0.25)\end{array}$ & & \\
\hline $\begin{array}{l}D A_{i} \\
\text { (As of year } t \text { ) }\end{array}$ & $\begin{array}{c}0.208^{*} \\
(1.75)\end{array}$ & $\begin{array}{l}0.191 \\
(1.29)\end{array}$ & $\begin{array}{c}0.198 * * \\
(2.35)\end{array}$ & $\begin{array}{c}0.231 * * \\
(2.17)\end{array}$ & $\begin{array}{l}0.170 \\
(1.23)\end{array}$ & $\begin{array}{l}0.228 \\
(1.23)\end{array}$ & $\begin{array}{c}0.213 * * * \\
(2.90)\end{array}$ & $\begin{array}{c}0.188^{*} \\
(1.67)\end{array}$ \\
\hline $\begin{array}{l}\text { NonDE } E_{i} \\
\text { (As of year } t \text { ) }\end{array}$ & & $\begin{array}{l}-0.030 \\
(-0.27)\end{array}$ & & $\begin{array}{l}0.037 \\
(0.36)\end{array}$ & & $\begin{array}{l}0.100 \\
(0.62)\end{array}$ & & $\begin{array}{l}-0.027 \\
(-0.26)\end{array}$ \\
\hline$R^{2}$ & 0.197 & 0.198 & 0.197 & 0.198 & 0.118 & 0.126 & 0.177 & 0.177 \\
\hline$F$ & $2.79 * *$ & $2.44 * *$ & $2.71 * *$ & $2.33 * *$ & 1.62 & 1.39 & $3.08 * *$ & $2.63 * *$ \\
\hline No. Obs. & 105 & 105 & 90 & 90 & 105 & 105 & 90 & 90 \\
\hline
\end{tabular}


Panel B: Estimation window for the calculation of CAR is $[-340,-31]$ days prior the announcement day (day 0)

\begin{tabular}{|c|c|c|c|c|c|c|c|c|}
\hline Dependent var. & \multicolumn{4}{|c|}{$\operatorname{CAR}[0,+1]$} & \multicolumn{4}{|c|}{ CAR $[-1,+1]$} \\
\hline Model & $\begin{array}{c}(1) \\
\text { Jones DA }\end{array}$ & $\begin{array}{c}(2) \\
\text { Jones DA and } \\
\text { NonDE }\end{array}$ & $\begin{array}{c}(3) \\
\text { Kothari ROA-matched } \\
\text { DA }\end{array}$ & $\begin{array}{c}(4) \\
\text { Kothari ROA-matched } \\
\text { DA and NonDE }\end{array}$ & $\begin{array}{c}(5) \\
\text { Jones DA }\end{array}$ & $\begin{array}{c}(6) \\
\text { Jones DA and } \\
\text { NonDE } \\
\end{array}$ & $\begin{array}{c}(7) \\
\text { Kothari ROA-matched } \\
\text { DA }\end{array}$ & $\begin{array}{c}(8) \\
\text { Kothari ROA-matched } \\
\text { DA and NonDE }\end{array}$ \\
\hline Intercept & $\begin{array}{c}0.187 * * * \\
(2.69)\end{array}$ & $\begin{array}{c}0.184 * * * \\
(2.65)\end{array}$ & $\begin{array}{c}0.143^{* *} \\
(2.37)\end{array}$ & $\begin{array}{c}0.147 * * \\
(2.37)\end{array}$ & $\begin{array}{c}0.172 * * \\
(2.43)\end{array}$ & $\begin{array}{c}0.184 * * \\
(2.39)\end{array}$ & $\begin{array}{c}0.150 * * * \\
(2.73)\end{array}$ & $\begin{array}{c}0.147 * * \\
(2.48)\end{array}$ \\
\hline $\operatorname{Lev}_{i}$ & $\begin{array}{c}-0.177 * * * \\
(-2.76)\end{array}$ & $\begin{array}{c}-0.176 * * * \\
(-2.72)\end{array}$ & $\begin{array}{c}-0.116 * * \\
(-2.07)\end{array}$ & $\begin{array}{c}-0.120 * * \\
(-2.10)\end{array}$ & $\begin{array}{c}-0.158^{* *} \\
(-2.10)\end{array}$ & $\begin{array}{c}-0.161 * * \\
(-2.10)\end{array}$ & $\begin{array}{c}-0.115^{*} \\
(-1.79)\end{array}$ & $\begin{array}{l}-0.112 \\
(-1.64)\end{array}$ \\
\hline $\operatorname{Ln}\left(T A_{i}\right)$ & $\begin{array}{l}-0.015^{*} \\
(-1.69)\end{array}$ & $\begin{array}{c}-0.014 * \\
(-1.68)\end{array}$ & $\begin{array}{l}-0.011 \\
(-1.58)\end{array}$ & $\begin{array}{l}-0.012 \\
(-1.57)\end{array}$ & $\begin{array}{l}-0.015 \\
(-1.39)\end{array}$ & $\begin{array}{l}-0.016 \\
(-1.45)\end{array}$ & $\begin{array}{l}-0.012^{*} \\
(-1.71)\end{array}$ & $\begin{array}{l}-0.011 \\
(-1.39)\end{array}$ \\
\hline$Q_{i}$ & $\begin{array}{l}-0.001 \\
(-0.11)\end{array}$ & $\begin{array}{l}-0.001 \\
(-0.14)\end{array}$ & $\begin{array}{l}-0.007 \\
(-0.95)\end{array}$ & $\begin{array}{l}-0.006 \\
(-0.77)\end{array}$ & $\begin{array}{l}0.004 \\
(0.43)\end{array}$ & $\begin{array}{l}0.005 \\
(0.52)\end{array}$ & $\begin{array}{l}-0.001 \\
(-0.08)\end{array}$ & $\begin{array}{l}-0.001 \\
(-0.20)\end{array}$ \\
\hline$Z_{i}$ & $\begin{array}{l}-0.009 \\
(-1.25)\end{array}$ & $\begin{array}{l}-0.009 \\
(-1.23)\end{array}$ & $\begin{array}{l}-0.001 \\
(-0.29)\end{array}$ & $\begin{array}{l}-0.002 \\
(-0.49)\end{array}$ & $\begin{array}{l}-0.007 \\
(-0.98)\end{array}$ & $\begin{array}{l}-0.007 \\
(-1.04)\end{array}$ & $\begin{array}{l}-0.002 \\
(-0.56)\end{array}$ & $\begin{array}{l}-0.001 \\
(-0.23)\end{array}$ \\
\hline$\left(E B I T_{i} / T A_{i}\right)$ & $\begin{array}{l}0.054 \\
(0.51)\end{array}$ & $\begin{array}{l}0.071 \\
(0.46)\end{array}$ & & & $\begin{array}{l}0.034 \\
(0.27)\end{array}$ & $\begin{array}{l}-0.041 \\
(-0.28)\end{array}$ & & \\
\hline $\begin{array}{l}D A_{i} \\
\text { (As of year } t \text { ) }\end{array}$ & $\begin{array}{c}0.211^{*} \\
(1.78)\end{array}$ & $\begin{array}{l}0.197 \\
(1.35)\end{array}$ & $\begin{array}{c}0.201 * * \\
(2.36)\end{array}$ & $\begin{array}{c}0.235 * * \\
(2.20)\end{array}$ & $\begin{array}{l}0.173 \\
(1.26)\end{array}$ & $\begin{array}{l}0.235 \\
(1.28)\end{array}$ & $\begin{array}{c}0.215 * * * \\
(2.90)\end{array}$ & $\begin{array}{c}0.191 * \\
(1.68)\end{array}$ \\
\hline $\begin{array}{l}N o n D E_{i} \\
\text { (As of year } t \text { ) }\end{array}$ & & $\begin{array}{l}-0.025 \\
(-0.22)\end{array}$ & & $\begin{array}{l}0.038 \\
(0.37)\end{array}$ & & $\begin{array}{l}0.106 \\
(0.67)\end{array}$ & & $\begin{array}{l}-0.025 \\
(-0.25)\end{array}$ \\
\hline$R^{2}$ & 0.199 & 0.199 & 0.198 & 0.200 & 0.120 & 0.128 & 0.180 & 0.180 \\
\hline$F$ & $2.84 * *$ & $2.47 * *$ & $2.74 * *$ & $2.37 * *$ & 1.66 & 1.42 & $3.12 * *$ & $2.65 * *$ \\
\hline No. Obs. & 105 & 105 & 90 & 90 & 105 & 105 & 90 & 90 \\
\hline
\end{tabular}

